IZA DP No. 8632

Immigration and Crime: New Empirical Evidence from European Victimization Data

Luca Nunziata

November 2014 


\title{
Immigration and Crime: New Empirical Evidence from European Victimization Data
}

\author{
Luca Nunziata \\ University of Padua \\ and IZA
}

\section{Discussion Paper No. 8632 \\ November 2014}

IZA

\author{
P.O. Box 7240 \\ 53072 Bonn \\ Germany
}
Phone: +49-228-3894-0
Fax: +49-228-3894-180
E-mail: iza@iza.org

\begin{abstract}
Any opinions expressed here are those of the author(s) and not those of IZA. Research published in this series may include views on policy, but the institute itself takes no institutional policy positions. The IZA research network is committed to the IZA Guiding Principles of Research Integrity.
\end{abstract}

The Institute for the Study of Labor (IZA) in Bonn is a local and virtual international research center and a place of communication between science, politics and business. IZA is an independent nonprofit organization supported by Deutsche Post Foundation. The center is associated with the University of Bonn and offers a stimulating research environment through its international network, workshops and conferences, data service, project support, research visits and doctoral program. IZA engages in (i) original and internationally competitive research in all fields of labor economics, (ii) development of policy concepts, and (iii) dissemination of research results and concepts to the interested public.

IZA Discussion Papers often represent preliminary work and are circulated to encourage discussion. Citation of such a paper should account for its provisional character. A revised version may be available directly from the author. 


\section{ABSTRACT \\ Immigration and Crime: New Empirical Evidence from European Victimization Data*}

We exploit the increase in immigration flows into western European countries that took place in the 2000s to assess whether immigration affects crime victimization and the perception of criminality among European natives. Using data from the European Social Survey, the Labour Force Survey and other sources, we provide a set of fixed effects and instrumental variable estimations that deal with the endogenous sorting of immigration by region and with the sampling error in survey based measures of regional immigration shares, whose implications in terms of attenuation bias are investigated by means of Monte Carlo simulations. Our empirical findings show that an increase in immigration does not affect crime victimization, but it is associated with an increase in the fear of crime, the latter being consistently and positively correlated with the natives' unfavourable attitude toward immigrants. Our results reveal a misconception of the link between immigration and crime among European natives.

JEL Classification: J15, J61, K42, F22, R23, O15

Keywords: crime, migration, victimization, perception, fear

Corresponding author:

Luca Nunziata

Department of Economics

University of Padua

Via del Santo 33

35121, Padua

Italy

E-mail: luca.nunziata@unipd.it

\footnotetext{
* The author is grateful to Tommaso Frattini for advice and suggestions; to seminar participants at the Centro Studi Economici Antonveneta (CSEA) workshop on Migration, University College London NORFACE Migration Conference, the ESPE Conference in Bern and the EALE Conference in Bonn for helpful comments; and to Veronica Toffolutti for research assistance. Financial support from CSEA is gratefully acknowledged. The usual disclaimer applies.
} 


\section{Introduction}

One of the issues that has dominated the political debate in recent years in most OECD countries pertains to the economic and social implications of increasing immigration in affluent economies. This debate has been particularly relevant in Europe, where immigration flows have steadily increased over the past few years, especially from developing areas of the world.

Economic theory provides some guidance regarding how immigration affects host countries, with the literature largely focusing on labor market outcomes and welfare-state provision. ${ }^{1}$ One dimension that has recently attracted increased attention is the implications of immigration in terms of criminality. This aspect of the immigration discussion is one of the most important in evaluating European natives' attitudes toward immigrants. (See Boeri, 2010; Card, Dustmann, and Preston, 2009.)

According to economic theory, the association between immigration and criminality may originate from the differences in the opportunity cost of committing a crime, as it is experienced by immigrants and natives (Becker, 1968). Since immigrants face reduced economic opportunities in host countries, they may be more prone to engage in criminal activities than natives are. In addition, immigration may increase the labor supply in specific skill groups, reducing wages and legal employment opportunities and increasing the propensity for those with such skills to commit crimes (Borjas, Grogger, and Hanson, 2010). Finally, the age composition of immigrants is generally much younger than that of natives, and the frequency of criminal activity among younger individuals is generally higher than among those who are older (Freeman, 1999). On the other hand, natives and immigrants may experience different costs of apprehension and conviction. Immigrants may find it harder to access to quality legal defense and face more dramatic consequences of conviction than natives do, including deportation. These costs may reduce the likelihood that immigrants will become criminals. Considering these conflicting factors, economic theory does not provide clear predictions for the criminality patterns induced by an increase in immigration, so the investigation of the relationship between migration and crime remains an empirical question.

Most of the empirical literature on the relationship between criminality and immigration concentrates on US data and is limited to actual crime outcomes in terms of crime reported,

\footnotetext{
${ }^{1}$ See, for example, Borjas $(1994,1999)$
} 
convictions, or victimization. Crime perception is usually left aside despite it may not be in line with actual reported crime for a number of reasons: citizens may be subject to cognitive bias in their representation of the amount of crime experienced in their local areas, and the traditional media attention to crime may lead to an over-representation bias in their portrayal of security issues. Crime perception, then, may be a useful measure of how citizens internalize social fears about criminality and whether those fears are justified in terms of actual criminality. This paper is the first attempt to investigate the relationship between immigration and crime with a European focus. It exploits the increase in immigration flows into western European countries that took place in the 2000s to assess whether immigration affects criminality rates and the perception of criminality among European natives. By matching individual crime victimization and crime perception data from the European Social Survey with immigration penetration data in European regions from the Labour Force Survey and other sources, the analysis provides an estimate of the effect of changes in immigration patterns on the crime rate and on the subjective perception of criminality.

Regional migration measures derived from survey data may be affected by sampling error with the risk of inducing substantial attenuation bias in empirical estimates (Aydemir and Borjas, 2011). In addition, immigration may be endogenous in a model of crime victimization or perception. In order to account for possible endogeneity and sampling error issues, we adopt alternative estimation techniques characterized by different degrees of generalization and derive and discuss each model's conditions of validity.

A first more restrictive specification with fixed effects by regions and country-specific time dummies is used to examine the effect of immigration on crime using alternative definitions of immigrant. A second specification deals with the problem of measurement error of regional immigration by instrumenting the European Social Survey measure of immigration using the immigration share derived from the Labour Force Survey as instrument, since the errors in the two surveys are independent. Finally, a third specification is based on a model in differences, where immigration is instrumented by using exogenous supply-push changes in migration patterns in order to account for measurement errors and time-varying omitted factors that are not captured by fixed effects.

We also provide a set of Monte Carlo simulations that investigate the sample region/year cell size required to calculate immigration shares that do not suffer from sampling error and 
allow an unbiased estimation of the parameter of interest with data like ours. The attenuation bias due to sampling error is found to be small when using fixed effects and practically zero when we use instrumental variables.

In all cases, the empirical results reveal no evidence of an increase in criminality from the recent immigration waves in Europe. However, the IV estimates suggest that an increase in immigration induces a rise in crime perception, and the fear of crime is found to be consistently and positively correlated with the natives' unfavourable attitudes toward immigrants. These results seem to suggest a misconception of the link between immigration and crime among European natives. The public's misperception of a causal effect from immigration to crime can only be partly imputed to the positive cross-sectional correlation found in simple pooled regressions with no regional fixed effects. This correlation is likely due to area-specific fixed omitted factors but it is too low to explain these findings fully. Others factors previously investigated by the literature can provide possible explanations for such a bias against immigration, including the media's misrepresentation of the immigration phenomenon and political opportunism in host countries.

The paper is organized as follows. Section 2 presents a review of the existing empirical literature, section 3 introduces the research design, section 4 provides a description of the data and presents the Monte Carlo simulations and the empirical findings, and section 5 concludes.

\section{Literature Review}

The empirical literature on the relationship between immigration and crime has found mixed results. Most of the published papers analyze US data. For example, Butcher and Piehl (1998) use Uniform Crime Reports and CPS data to identify a cross-sectional correlation between criminality and immigration rates across US cities. However, the correlation disappears after controlling for the cities' demographic characteristics. No correlation is found using within-city variation in crimes and immigration.

In looking at three US border cities (Miami, El Paso, and San Diego), Lee, Martinez, and Rosenfeld (2001) find that immigration does not increase the number of homicides among Latinos and African Americans.

Butcher and Piehl (2007) show that immigrants in the US have much lower (around $20 \%$ 
lower) incarceration rates than natives do. This difference increased from 1980 to 2000 and does not appear to be driven by an increase in deportation. The authors suggest instead that the immigration process selects individuals who are less prone to criminality or who respond more to deterrence than the average native-born citizen does.

Moehling and Piehl (2007) use early twentieth-century US prison data to find analogous crime patterns for natives and immigrants, with minor exceptions. More specifically, in 1904 prison commitment rates for more serious crimes were similar for all ages except immigrants having higher commitment rates than natives at ages eighteen and nineteen. In 1930 immigrants were more likely to be committed to prison than natives were for violent offences. However, they were less likely to be convicted for other types of crimes.

The analysis in Spenkuch (2011) focuses on a panel of US counties observed from 1980 to 2000 and shows that an increase in immigration leads to an increase in crime. The result is stronger for crimes motivated by financial gain and among immigrants with poor labor opportunities.

Researchers have only recently drawn their attention to European data. Bianchi, Buonanno, and Pinotti (2008) use police administrative data to examine empirically the relationship between crime and immigration across Italian provinces from 1990 to 2003. Using the within province variation in the data, the authors find a positive correlation between the size of an immigrant population and the incidence of property crimes and the overall crime rate. However, the relationship disappears when immigration is properly instrumented, except for a significant effect on robberies. The effect on the overall crime rate is negligible since robberies are only a small fraction $(1.5 \%)$ of total criminal offences.

Mastrobuoni and Pinotti (2010) look at the implications of immigrants' legal status on criminal behavior by using exogenous variation in immigration-restriction laws in Italy. They focus on the last round of European Union enlargement that took place in 2007, when Romania and Bulgaria entered the European Union, to show that obtaining legal status reduces the propensity to commit crimes by raising their opportunity cost.

Bell, Machin, and Fasani (2010) analyze two recent large immigration waves in the UK to investigate the implications of immigration on the crime rates. Focusing on the large immigration wave of asylum-seekers in the late 1990s/early 2000s and the large inflow of workers from EU accession countries from 2004 onward, the authors argue that the opportunity costs 
of engaging in criminal offences were radically different for the two groups of immigrants. The asylum wave was associated with low labor force participation, high unemployment, and low wages, while the EU enlargement wave was characterized by higher labor participation rates than that of natives. The empirical analysis is consistent with the standard economic theory of crime, with non-violent crime rates found to be significantly higher in areas in which asylum seekers are located and not in areas affected by the EU enlargement wave.

Overall, the existing literature on the US and selected European countries is not conclusive regarding the effect of immigration on crime, and the perception of crime is rarely discussed. However, various studies in criminology have focused on the fear of crime, defined as the fear of being a crime victim as opposed to the actual probability of being a crime victim (Hale, 1996; Jackson and Stafford, 2009). Fitzgerald, Curtis, and Corliss (2012) suggest that fear of crime is a predictor of the attitude toward immigration in Germany, with a larger effect during election years. The actual drivers of these fears may be enhanced by cultural factors or by political and media representations of the immigration phenomenon.

What follows provides further empirical evidence on the relationship between immigration and crime with a comprehensive analysis of Western European data from 2002 to 2008, a period characterized by large migration inflows. Our focus is on both actual victimization and perception.

\section{Research Design}

\subsection{Sampling Error and Endogeneity}

The analysis is based on individual data on crime victimization and crime perception from the first four waves of the European Social Survey (ESS henceforth), covering multiple European countries every two years from 2002 to 2008. The time span of the analysis covers an important period for immigration in Europe, which was characterized by a significant increase in immigration penetration in most countries, although with a certain degree of regional heterogeneity within and across countries. The advantage of using survey data lies in relying on a measure of crime victimization that is not affected by the problem of under-reporting of crimes that is typical of administrative and judicial sources.

Although the ESS provides information on both western and eastern European countries, 
we choose to focus on the former in order to capture the relationship between immigration and outcomes of interest within an homogeneous economic and social environment. In addition, rather than being typical destination countries, eastern European countries are often the source of emigration outflows toward Western Europe, so they do not qualify for the empirical test (Bauer and Zimmermann, 1999).

The ESS reports the respondents' region of residence, which is classified according to various degrees of geographical aggregation (NUTS 1 or 2) according to country. The region of residence can be matched with a set of corresponding measures of immigration concentration in the region, and the within-region variation in immigration or some instrumented change in immigration can be used to address the questions of interest.

No homogeneous administrative data on regional immigration exist for all countries and years in the sample. We therefore rely on survey data to measure immigration shares across regions and years.

Survey data information on regional immigration is not necessarily limited to legal immigrants, as is the case with official administrative sources. However, both legal and illegal immigrants may be less inclined than natives to be interviewed and the region/year cell size may be too small to derive regional immigration measures that are immune from sampling error. As a consequence, our estimates may suffer from an attenuation bias, especially when regional fixed effects are included in the model. Our research design should therefore address sampling error.

We calculate immigration shares by region and year from the European Labour Force Survey (LFS henceforth). The LFS, with its large sample size corresponding to sampling rates that vary between 0.2 and 3.3 percent of total population is characterized by an average region/year cell size varying between 2977 and 115508 respondents across countries and years and it is therefore close to the minimal acceptable cell size suggested by the literature in similar contexts where sampling error may be an issue (Aydemir and Borjas, 2011). Nevertheless, in what follows we investigate the extent of the attenuation bias induced by sampling error by means of Monte Carlo simulations, providing an evaluation of the attenuation bias in our setting and proposing possible solutions.

A further problem in our analysis is endogeneity, since immigration is not randomly assigned to regions but may be endogenously driven by factors that directly relate to criminality and 
crime perception, resulting in biased estimates and misstated policy implications.

In order to solve possible endogeneity and sampling error problems, we adopt three alternative empirical strategies that differ according to their degree of generalization. By comparing the empirical results under different assumptions regarding the nature of the measurement error and of omitted factors, we aim at testing the robustness of the empirical findings.

The first empirical strategy is to adopt a fixed effects approach by matching individual-level crime victimization and crime perception with regional variation in immigration penetration. The model investigates whether a relationship exists after controlling for regional time-invariant and country-specific, time-varying, unobserved, confounding factors. The identification is obtained through the variability in immigration penetration and crime victimization within geographical areas, using LFS data for calculating regional immigration under different definitions of immigrant (born abroad, foreign national or born outside Europe). This is the most restrictive model since it assumes that both measurement error and omitted factors are composed of two elements that are (i) regional-specific and time invariant, and (ii) country-specific and time-varying.

The second strategy allows the sampling error in regional immigration to be random and adopts a more general fixed-effects model, where the potentially mismeasured immigration penetration by region and year is instrumented using a second measurement of regional immigration whose measurement error is independent. This split-sample instrumental variable strategy amounts to instrument the regional immigration share calculated using ESS data by means of the LFS measurement, since the two survey designs are independent. In this case, the fixed effects still capture possible omitted variables, and the sampling error problem is solved by instrumental variables.

Finally, the third strategy adopts a model in differences, where unobservable factors are allowed to vary over time in a way that is not captured by country-specific year fixed effects. Immigration is then instrumented using exogenous migration flows to Europe originated by exogenous push factors from areas of provenience, following the approach by Card (2001). This is the most general approach since time-varying omitted factors at the regional level are accounted for.

The comparison of the empirical findings obtained using each empirical strategy, should provide a robust assessment of the effect of immigration on crime victimization and crime 
perception in Europe.

\subsection{Baseline Fixed-effects Model}

The first and most restrictive empirical strategy adopts a fixed-effects model by pooling the four ESS waves (2002, 2004, 2006, and 2008), gathering measures of immigrants across European regions in each wave year, and using the within-region variation of immigration in order to estimate the immigration's effect on the probability of being a crime victim (or feeling not secure). In other words, we specify a model with regional fixed effects and clustering, as well as country-specific time dummies, controlling for observable individual and structural regional characteristics, and assuming that both unobservable factors that influence immigration patterns and measurement errors are constant by region but may vary each year following a country-specific non-linear pattern. Therefore, the linear probability model is:

$$
\text { crime }_{\text {crit }}=\beta m_{c r t}+\lambda^{\prime} \mathbf{X}_{i t}+\mu_{r}+\mu_{c t}+\varepsilon_{i t},
$$

where $_{\text {crime }}$ crit is a dummy variable that indicates whether individual $i$ 's household, living in country $c$ and region $r$ at time $t$, is a crime victim (or whether the individual fears crime); $\mathbf{X}_{i t}$ is a matrix of individual characteristics; $\mu_{r}$ are regional fixed effects; and $\mu_{c t}$ are country-specific time dummies.

This approach is successful if no time-varying unobservable regional characteristics affect both crime (or perception of insecurity) and immigration, thereby causing a spurious correlation between the two variables. However, country-level changes in unobserved country characteristics are admitted. For example, if the immigrants' location choice is motivated by each regions' fixed characteristics, and if such characteristics are correlated with crime, the model still provides an unbiased estimate of the population parameter of interest. Similarly, the estimates are still unbiased if unobserved country-level factors, that affect both immigration and crime, change over time.

Various sources of error may affect our measure of the share of immigrants by region. First, considering that immigrants are a small fraction of the total population in most European regions, the percentage of immigrants provided by survey data for each region/year may be affected by sampling error, especially if the region/year cell size is small. Second, illegal im- 
migrants may be misrepresented in the interview sample or not counted at all. Third, legal immigrants may be less inclined to participate to a survey than native-born residents.

In response to the first possible source of error, the Monte Carlo simulations presented below show how the average LFS region/year cell size is large enough to exclude any sizable attenuation bias coming from sampling error in our regional immigration measures.

As far as illegal immigration is concerned, previous analyses show that the relative dimension of illegal immigration with respect to legal immigration is fairly stable over time. For example, Bianchi, Buonanno, and Pinotti (2008) use regularization episodes in Italy to show that the ratio of illegal to legal immigrants is stable within Italian provinces and regularization years. If this is the case, our specification should be able to capture the overall effect of interest.

In response to the third possible source of measurement error, model (1) assumes either that the differences in the propensity to participate in the survey of legal immigrants is constant or it changes across regions and $\backslash$ or across time. If it changes across time, the change follows country-specific motives. All of these possible scenarios are accounted for by the fixed-effects specification in (1) through region- and country-specific time dummies.

In analytical terms, the LFS measure of the share of immigrants in the resident population $M^{\text {survey }}$ in each region $r$ of country $c$ at time $t$ is assumed to be proportional to the actual migration penetration $M^{\text {total }}$ according to the following relationship:

$$
M_{\text {crt }}^{\text {survey }}=M_{\text {crt }}^{\text {total }}\left(1+\nu_{r}+\nu_{c t}\right)
$$

where $\nu_{r}$ and $\nu_{c t}$ are region- and country/time-specific proportionality factors. In other words, the proportions vary independently by region and change across time according to country-specific time paths.

Taking logs, equation (2) approximates to:

$$
m_{c r t}^{\text {survey }} \approx m_{c r t}^{\text {total }}+\mu_{r}+\mu_{c t}+\varepsilon_{c r t}
$$

which, together with the need to control for unobservable factors by region and country/year, is the rationale for the specification of the fixed-effects model (1). If the assumptions above hold, the estimates presented in section 4.3 capture the causal impact of immigration on our variables of interest. Model (1) can be estimated using alternative definitions of immigrant and 
calculation methods using LFS data.

\subsection{Split-Sample Instrumental Variables Model Using a Second In- dependent Measurement of Immigration as Instrument}

The conditions implied by model (1) on the measurement errors of regional immigration may be too restrictive and not supported by the data. In addition, in case of sampling error the attenuation bias is likely to be exacerbated by the fixed-effects specification. A possible solution to this limitation is to consider the error in regional immigration to be random. If that is the case, assuming a classic error in variables framework, we may solve the measurement error problem by means of a split-sample instrumental variables (SSIV) approach (Reiersol, 1941; Durbin, 1954; Griliches and Mason, 1972; Angrist and Krueger, 1995), where potentially mismeasured regional immigration is instrumented using a second measure of regional immigration obtained from a different survey whose design is independent.

Under this approach, we assume that omitted variables are still captured by regional and country-specific time fixed effects so that the true unobserved measure of immigration $m^{*}$ is uncorrelated with the stochastic error $\varepsilon$; that is:

$$
E\left(m^{*} \varepsilon\right)=0
$$

Let us assume our observed measure of immigration $m_{1}$ is measured with error $e_{1}$, i.e.:

$$
m_{1}=m^{*}+e_{1}
$$

Let us also suppose that an alternative measure of regional immigration $m_{2}$, measured with error $e_{2}$, is available, such that:

$$
m_{2}=m^{*}+e_{2}
$$

Since both $m_{1}$ and $m_{2}$ are uncorrelated with $\varepsilon$, we need only for $e_{1}$ with $e_{2}$ to be uncorrelated in order to use $m_{2}$ as instrument for $m_{1}$, since the two measures are correlated through $m^{*}$.

ESS and LFS data provide two alternative measures of regional immigration penetration by region/year, each of which may be mismeasured. Given that the two survey designs are independent, we can use both measures to implement a SSIV estimation since the two mea- 
surement errors are uncorrelated. The ESS immigration measure is likely to suffer from serious sampling error given the small region/year average cell size in the ESS. As indicated by our Monte Carlo simulations below, small cell sizes are likely to generate a large attenuation bias in a fixed effects setting. However, the simulations also show how a SSIV design can drastically reduce the attenuation bias when the instrument is measured from large enough region/year cell sizes, like in the case of LFS data. The empirical findings under this approach are presented in section 4.4 .

\subsection{Instrumental Variables Model in Differences with Supply Push Factors as Instruments}

Unobservable factors correlated to immigration patterns may vary over time in a way not captured by country-specific time effects, in which case our fixed effects specification may still produce biased estimates. For example, a change in unobservable economic factors in one region may affect both the crime rate and the immigration rate inducing a spurious correlation between immigration and crime that our fixed effects or SSIV specifications could not eliminate.

A more general instrumental variable approach may then be advisable in this setting for two reasons. First, it can account for regional-specific omitted time-varying factors (which are not captured by regional dummies or by country-specific time-dummies) that may affect migration patterns and crime victimization or the perception of insecurity among respondents. Second, we may be able to account for more complex structures of measurement errors in regional immigration.

Various instruments have been suggested by the literature. For example, Lemos and Portes (2008) and Bell, Machin, and Fasani (2010) instrument recent migration patterns from eastern Europe toward UK regions using the availability of flights from Eastern Europe to the UK. Card (2001), Dustmann, Frattini, and Preston (2008) and Bianchi, Buonanno, and Pinotti (2008) use instead the predetermined geographical distribution of previous immigrants' flow areas to construct an instrument for subsequent flows.

We follow this second approach, and like what Bianchi, Buonanno, and Pinotti do with Italian data, we use exogenous migration flows to Europe as instruments in a specification in differences. These differences are measured by changes in migration flows toward European 
regions from world areas of provenience, weighted by the predetermined share of immigrants from the same areas located in each region. These changes in immigration patterns account for the exogenous supply-push factors that increase immigration from each area of provenience. These supply-push factors in areas of origin can be related to wars, political repression, famine, economic stagnation and other events, so they are exogenous to our outcome of interest. The exogenous changes in migration waves are weighted by the predetermined share of immigrants previously located in that region from each area of origin, since immigrants tend to locate in areas that previously hosted individuals from the same area of provenience (Munshi, 2003).

In our specification in differences, the changes in crime victimization are regressed on changes in migration penetration. Assuming we have $N$ possible world flow areas $a$ and that, prior to the period under investigation, each region $r$ in country $c$ is characterized by a certain share $s_{c r}^{a}$ of immigrants from each area, then the change in immigration in that region will be approximately equal to:

$$
\Delta m_{c r t} \approx \sum_{a=1}^{N} s_{c r}^{a} \Delta \ln M_{c r t}^{a}-\Delta p o p_{c r t} .
$$

Equation (7) provides a basis for constructing an instrument for $\Delta m_{c r t}$, aimed at solving possible endogeneity and measurement error problems. To this end, we define the exogenous changes in immigration from each flow area of origin $a$ as the change caused by supply-push factors only. These factors pertain to each flow area of origin and are unobservable. However, the consequences of these factors may be observed by looking at the marginal changes in global immigration patterns of individuals from each area $a$.

In each European region, however, the change in immigration from area $a$ to region $r$ may be due to both exogenous supply push and endogenous demand pull factors that pertain to the region of destination. Therefore, we eliminate any change in regional immigration that could be due to demand-pull factors at the local level by considering the changes in immigrants from each flow area of origin $a$ in all regions other than $r$. This process amounts to substituting $M_{c r t}^{a}$ with $M_{k t}^{a}$ in equation (7), where $k \neq c r$. Therefore, our instrument becomes:

$$
z_{c r t}=\sum_{a=1}^{N} s_{c r}^{a} \Delta \ln M_{k t}^{a}-\Delta p o p_{c r t}, \quad k \neq c r .
$$

Expression (8) identifies an instrument for the total change in immigration in country $c$, 
region $r$, and time $t$ by using the changes in immigration from flow area $a$ caused by exogenous supply-push factors observed in all regions excluding $r$, weighted by the predetermined share of immigrants from area $a$ in region $r$.

Our definition of flow areas $a$ is the one provided by the Census collected in 2000, i.e. prior to our time-frame of analysis. Therefore, in our baseline specification we consider $N=12$ subcontinental flow areas, ${ }^{2}$ for each region, and we derive the predetermined share at the regional level, that is, $s_{c r}^{a}$.

The instrument in the baseline IV model becomes:

$$
z_{c r t}=\sum_{a=1}^{N} s_{c r}^{a} \Delta m_{k t}^{a}-\Delta p o p_{c r t}
$$

By instrumenting $\Delta m_{c r t}$ with (9) and including a set of regional controls $W$, we then estimate the following model of crime victimization (or perception) in differences:

$$
\Delta c_{c r t}=\beta \Delta m_{c r t}+\gamma^{\prime} \mathbf{W}_{c r t}+\varepsilon_{c r t}
$$

The estimates of this model are reported in section 4.5.

\section{Empirical Analysis}

\subsection{The Data}

Our sample is constituted of 16 western European destination countries, i.e. Austria, Belgium, Switzerland, Germany, Denmark, Spain, Finland, France, Greece, Ireland, Luxembourg, Netherlands, Norway, Portugal, Sweden and the UK. The total number of regions covered is 127, with most regional codes being NUTS 2 with the exception of Belgium, France, Germany, Denmark, Luxembourg and the UK whose regional codes are NUTS $1 .^{3}$

The ESS provides individual level information on crime victimization, i.e. on whether the respondent or a household member has been the victim of assault or burglary in the last

\footnotetext{
${ }^{2}$ These are North America, South and Central America, northern Africa, southern Africa, Near and Middle East Asia, other Asian countries, Oceania, northern Europe, western Europe, eastern Europe, southern Europe, EFTA countries.

${ }^{3}$ According to the NUTS classification, NUTS 1 regions are characterized by a population of 3-7 million individuals, whereas NUTS 2 regions are between 800,000 and 3 million individuals.
} 
five years. The two types of crime the ESS accounts for, assault and burglary, constitute a significant proportion of all reported crimes. Aggregate European data on types of crime shows that the incidence of assault and burglaries is generally correlated with the extent of other kind of thefts. Table 1 reports the average yearly incidence of types of crimes in Europe (Eurostat, 2012). Although the categories in the table do not directly overlap with the ESS question, the sum of violent crimes, robberies, and domestic burglaries should in part reflect the victimization measured by ESS as constituting around 20 percent of total crimes recorded by the police in western Europe. The ESS crime victimization measure does not account for motor vehicle theft and larceny-theft, that is, those crimes that are not characterized by the use of force or fraud (e.g., shoplifting and pickpocketing). According to Table 1, motor vehicle theft constitutes less than 2 percent of total offences. As far as larceny theft is concerned, US Department of Justice data show that this type of crime usually consists of minor offences that represent a larger share of total crimes (United States Department of Justice, 2011). However, not all larceny-thefts matter when considering individual crime victimization (as in the case of shoplifting, for example).

Figure (1) provides a summary of crime victimization rates across European regions as portrayed by ESS data. The regions most affected by crime victimization are central UK, southern France, the Paris area, Belgium, Luxembourg, and Finland. The least affected are Austria, Germany and some areas of Portugal, Spain and Greece.

Survey data can provide more accurate measures of crime victimization with respect to administrative sources since they collect information on all crime events, including those that were not reported to the police (Buonanno, Drago, Galbiati, and Zanella, 2011; Lauritsen and Rezey, 2013). However, some authors (Levine, 1976) suggest that respondents may be inclined to over-report in crime victimization surveys. This may be due to misjudgment of events, prefabrication, problems with recollection of when an event took place, or difficulty in interpreting the survey question or the legal definition the survey refers to. On the other hand, crime figures may be under-reported if respondents may be embarrassed to deal with sensitive topics or in case of oversight of actual crime incidents. We cannot exclude that some of these limitations apply to our data. Nevertheless, since we exploit the within regional variation in both immigration and crime events, our models are still valid if the reported crimes are consistently higher or lower on average at the regional level, or if mis-reporting 
follows country-specific time patterns. In addition, the ESS crime victimization data refer to very specific typologies of crimes (burglary and assault) that are less likely to create difficulties in interpreting the survey question or embarrassment to the respondent.

Nevertheless, the possibility of oversight of actual crime incidents may be particularly relevant in our setting since the timing to which the ESS question on crime victimization refers to is a five years interval. As noted by the survey methodology literature (see for example Strube, 1987 and Kessler and Wethington, 1991), individuals tend to have difficulties reporting events in the past. Survey respondents have been shown to report severe negative events with reliability over a twelve-month recall period only. ESS crime victimization data is therefore likely to report crime events occurred in the recent past rather than several years before.

In our analysis we will therefore analyze the relationship between crime victimization and immigration using measures of regional migration penetration referring to different time spans (immigration in the last five years, in the last two years or current) in order to account for the possibility of a shorter recall period, as well as perfect recollection.

The ESS measure of fear of crime is a variable that depicts the feeling of safety when one is walking alone in local area after dark, using four categories, i.e. "very safe", "safe", "unsafe" or "very unsafe." Figure 2 shows crime perception across European regions, measured by the percentage of residents who feel safe or very safe when walking alone after dark. Normally, crime victimization and fear of crime are correlated, however victims are only around 10 percentage points more likely to feel unsafe. Not surprisingly, citizens in Germany tend to feel safe since they experience particularly low crime victimization rates, but the pattern is less clear in other countries, such as Norway, Sweden, and Finland, where citizens feel safe despite the relatively high rate of crime victimization in certain areas. Table A.1 in the appendix provides some summary statistics of the data, including the rate of victimization by country and the proportion of individuals who feel unsafe or very unsafe when walking alone after dark.

The only coherent administrative measure of immigration across European regions is Census data, which is however available only for limited years. Our main data source for regional immigration is therefore LFS data, that is characterized by sampling rates that vary between 0.2 and 3.3 percent of total population and average region/year cell sizes that vary between 2977 and 115508 respondents across countries. Immigration shares are calculated for the previous five years in order to match them with victimization data, as well as for the previous two years 
and current.

Our preferred definition of immigrant is, in line with most of the literature, an individual who is born abroad. This definition avoids the distortions caused by differences in legislation about naturalization across countries. According to Boeri (2010), the born-abroad concept may result in some bias in countries that have former colonies, where nationals born in those colonies and returning to the home country may be incorrectly counted as immigrants. However, the data show that the definition based on citizenship tends to underestimate regional immigration, even by comparison with the 2001 census data. ${ }^{4}$ We believe that, in our setting, the second type of bias is less relevant than the first type, so our preferred specifications adopt a measure of born-abroad regional immigration for all countries except Germany for which we only observe the regional share of foreign nationals. In addition we test the robustness of our findings adopting other definitions of immigration, i.e. foreign nationals and born outside Europe. ${ }^{5}$

Of all immigrants born abroad who were surveyed by the LFS, around 71 percent are born in non-European countries. Figure (3) displays the percentage of immigrants in the total residential population in European regions. Summary statistics by country are reported in Table A.1 in the appendix.

\subsection{Attenuation Bias from Sampling Error in Regional Immigration Shares: Monte Carlo Simulations}

Our measure of regional immigration shares is calculated from survey data and therefore it may be affected by sampling error that in turn may lead to attenuation bias in our estimates. The problem may be aggravated by the inclusion of fixed effects in our specification. Aydemir and Borjas (2011) suggest that the bias generated by sampling error may be substantial even when the aggregate mean of the immigration share is precisely estimated and the cell size used to calculate the immigration share is large (i.e. in the order of 1000 observations). However they also show that, in their data, SSIV methods can correct the attenuation bias when the average cell size counts at least 1000 observations. The average number of observations per cell in our LFS data is large (i.e. 13451 in total, that is between 2977 and 115508 according to

\footnotetext{
${ }^{4}$ See Table A.2 in the appendix.

${ }^{5}$ In this paper we consider only first-generation immigrants, as the second generation is counted as native. The implication of second- versus first-generation immigration on criminality and perception of insecurity may be a topic on its own.
} 
country) which puts us on the safe side with respect to the indications of Aydemir and Borjas's simulations. Nevertheless, we further investigate how serious the attenuation bias can be in a setting like ours by performing a set of Monte Carlo simulations.

Our simulations are based on an artificial population of 10 millions individuals distributed across 100 regions. We assume a given initial share of immigration per region (in the order of the average immigration share in our sample) that each period, and for four subsequent periods, like in our data, is subject to a random positive immigration shock that varies across regions plus a random positive shock common to all regions. We then build a population model where we impose that the probability to be a crime victim depends on the share of immigrants in each region plus region and year fixed effects, so that the resulting average probability to be a crime victim is equal to 20 percent like in our data. Finally, we draw 500 random samples, using different sampling rates, covering all regions and years, and we estimate our fixed effects model (including region and year fixed effects) or SSIV model in each of the 500 random samples, producing an averaged estimated coefficient of interest and standard error across the 500 replications. Our aim is to check the extent of the attenuation bias for randomly drawn samples of different sizes, i.e. for region/year cells of different sizes.

Table 2 reports a selection of our Monte Carlo simulations ${ }^{6}$ where the average sample cell size used to calculate the immigration share varies with the sampling rate. Despite the average immigration share is very precisely estimated even for very low sampling rates, the attenuation bias can be large in fixed effects estimations when the sampling rate is low. Our estimations show that in presence of a unitary effect of immigration on crime at the population level we observe a 52 percent bias when the sampling rate equals 5/1000 (average cell size of 522), 35 percent bias when the sampling rate equals $1 / 100$ (average cell size of 1043) and 15 percent bias when the sampling rate equals 3/100 (average cell size of 3130). However a positive, albeit biased, and statistically significant effect of immigration on crime is found even when the sampling rate is as low as 5/10000 (average cell size of 52) as shown in the Appendix.

The lower part of the table displays the SSIV findings for different sampling rates (from $1 / 1000$ to $1 / 100)$ in the second sample used for the SSIV estimations. We assume that the instrumented immigration share is derived from smaller cell sizes (as in ESS data) while the instrumenting immigration share is calculated from larger cell sizes (as in LFS data). Our SSIV

\footnotetext{
${ }^{6}$ For further details on the Monte Carlo simulations see Appendix A.3 and the full tables therein.
} 
model largely outperforms the fixed effects model, resulting in a very small attenuation bias even for very low sampling rates. When the instrumented immigration share is derived from a sampling rate equal to $1 / 1000$ (average cell size of 104 ), the bias is consistently lower than 5 percent for sampling rates used to calculate the instrumenting immigration share equal or greater than 5/1000 (average cell size of 522). The bias is consistently lower than 1 percent when the first sampling rate is equal to or greater than $5 / 1000$.

We also perform a set of Monte Carlo simulations in order to test whether our estimates in differences suffer from an attenuation bias that may be induced by spurious changes in victimization rates generated by the small size of the region/year cells in ESS data (the average region/year cell size in the ESS data amounts to 246 observations). Assuming a victimization rate equal to 20 percent, as in our data, our simulations show ${ }^{7}$ that an OLS model in differences analogous to (10) yields estimates that are unbiased even for region/year cell sizes as low as 100.

Our findings confirm and reinforce the claims by Aydemir and Borjas and suggest that the fixed effects estimates of model (1) may be subject to an attenuation bias, although the extent of the bias should be small in our context, given that the average cell size in LFS data is large. Moreover, we should be able to identify a significant effect of immigration on crime victimization or perception, if present, even when the data are affected by limited sampling error. In addition, according to the simulations, the SSIV estimates should be practically unbiased if the average cell size used to calculate the instrumenting immigration share is large enough (as in the LFS sample) even in presence of small cell sizes in the ESS sample. Finally, the IV estimates in differences of model (8) should be able to tackle the endogeneity of immigration as well as sampling error without being affected by any attenuation bias toward zero generated by spurious changes in victimization. The empirical results obtained from the estimation of each model discussed above are presented in the next sections.

\section{FIGURES 1,2 AND 3 AROUND HERE}

\footnotetext{
${ }^{7}$ Not reported, available upon request.
} 


\subsection{Baseline Fixed Effects Estimations}

We estimate the fixed-effects model in (1), adopting a linear probability model specification. Since we are interested in the average effect of immigration on crime, this linear estimator allows consistency without requiring a specific distributional assumption of the error term, as would be the case with Probit and Logit ${ }^{8}$. The resulting heteroskedasticity is accounted for by clustering.

Table 3 reports our baseline findings where crime victimization is regressed on immigration over the last five years, measured as the share of residents who are born abroad, across alternative model specifications. When fixed regional effects are not included, as in columns 1 and 2, a statistically significant positive correlation, albeit small, exists between immigration and crime victimization. This corresponds to a 0.45 percentage point increase in victimization when immigration increases by 10 percent if non-demographic individual level controls (such as educational attainment, degree of urbanization of local area, and whether the main source of income is financial, i.e. a measure of the respondent's wealth) are excluded. The increase is equal to 0.28 percentage point when the controls are included. However, when we add regional fixed effects the correlation is never statistically significant.

Similar findings are obtained re-estimating the model using alternative measures of immigration as displayed in Table 4. Here we consider born-abroad immigration penetration in the last five years, a weighted average of immigration penetration over the last five years giving 70 percent of the weight to the last two years, current immigration, foreign national immigration and immigration from Europe and from outside Europe over the last five years. Our empirical findings show that immigration is statistically significant when regional fixed effects are not included in the model (except for immigration from other European countries that is never correlated with victimization). When we account for regional unobservables the coefficient is consistently not statistically significant with the only exception of immigration from outside Europe that is found significant at the 10 percent level only.

\section{TABLES 3 AND 4 AROUND HERE}

Our estimates indicate that males are more likely to report a crime victimization episode than females (typically by around 1 percentage point). If the main source of income is financial,

\footnotetext{
${ }^{8}$ For a similar approach, see Angrist and Evans (1998). In our setting, Probit and Logit estimations provide similar findings.
} 
i.e. if the respondent is wealthy, crime victimization increases by around 6 percentage points. As regards the other controls, in a typical regression the farther from a large city the individual lives, the lower is crime victimization, with victimization in rural areas around 9 percentage points lower than that in large cities. Educational attainment is also significant, with higher education correlated with a higher victimization. In addition, crime victimization decreases with age. ${ }^{9}$

A comparison of the empirical findings with and without regional fixed effects may help partly explain why some may be induced to see the increase in immigration as related to increased criminality. While regions with more immigrants are also those where crime victimization is slightly higher, this spurious relationship seems to be explained by unobserved regional characteristics that attract immigration and correlate with criminality, rather than pointing to a causal relationship from immigration to crime.

Table 5 reports the effect of immigration on crime perception or fear of crime, where the latter is defined as feeling unsafe or very unsafe when walking alone after dark or only as feeling very unsafe. In other words, the tables account for different degrees of crime perception by the respondents. Here we do not find signs of a significant positive effect of immigration on crime perception, except for the feeling of unsafety when regional fixed effects are excluded.

\section{TABLE 5 AROUND HERE}

As regards the controls, males tend to feel safer when walking alone after dark in the local area (around 18 percentage points safer than females), as do more educated respondents and those who live in less urbanized areas. In addition, as expected, crime perception increases with age.

\subsection{Split-Sample IV Estimations}

Our Monte Carlo simulations seem to exclude that our fixed effects findings may be driven by an attenuation bias, however they also suggest that the precision our estimates is likely to increase when we adopt a split-sample IV specification. Table 6 presents a set of IV models in which the regional immigration share is instrumented using a second measurement of regional

\footnotetext{
${ }^{9}$ All displayed results in the paper are obtained without using survey weights. Almost identical findings are obtained by weighting each observation using population and survey design weight.
} 
immigration provided by an independent alternative data source, as discussed in section 3.3. Assuming both measures are affected by sampling error and are correlated with the unobservable true measure of regional immigration, we may use one measurement as instrument for the other when the errors are independent.

\section{TABLE 6 AROUND HERE}

We follow the same specification we adopted in our simulations, i.e. we instrument the immigration share derived from a smaller sample with the one derived from a larger sample. Our instrumented measure of immigration is therefore calculated from ESS data and it is likely to suffer from sampling error given the small region/year cell size in that dataset. Our instrument is derived from LFS data, i.e. it is calculated from cells of much larger sizes.

Table 6 provides a set of SSIV estimates with and without fixed effects, where the definition of immigrants is either born-abroad, foreign national or born outside Europe. In all cases the first-stage regressions indicate that the instrument is highly correlated with the potentially mismeasured regressor with $t$-statistics in the range between 15 and 30 when regional fixed effects are included. In all cases the SSIV estimates confirm what was found in section $4.3-$ that is, no significant effect of immigration on crime. In addition, the effect is only significant when we drop regional fixed effects, as before, with a coefficient equal to 0.031 that is pretty close to the coefficient of 0.028 found using OLS, as displayed in column 2 of Table $3 .{ }^{10}$ When we drop the regions whose ESS immigration share is likely to be seriously mis-measured, i.e. whose cell size is lower than 100 observations, the estimated coefficient, reported in column 3, is larger but still not statistically significant.

No significant effect of immigration on crime perception is found using a SSIV specification. ${ }^{11}$

\section{TABLE 6 AROUND HERE}

\subsection{Estimations Using Supply-Push Factors as Instruments}

The empirical findings of the previous sections may still be plagued by omitted confounding factors that are not captured by our fixed effects specification. The model in differences dis-

\footnotetext{
${ }^{10}$ Here, the number of observations is slightly lower with respect to the baseline fixed effects estimates in Table 3 because of the missing values in the ESS (and not in the LFS) immigration penetration measure of born abroad and non-nationals for a small number of combinations of region/year.

${ }^{11}$ Not reported, available upon request.
} 
cussed in section 3.3 is the most general of the adopted specifications since it does not require any restrictive assumption regarding omitted variables. Equation (10) is estimated by instrumenting the change in regional immigration with the exogenous supply-push factors given by (9). The predetermined share of immigrants by geographical areas of origin in each European region in 2000 is provided by Census data. Immigrants' world areas of origin are classified using the Census classification and consist of $N=12$ possible origins for immigrants, which include the major sub-continental macro areas.

Table 7 provides a set of IV regressions in differences, where the data has been collapsed at the regional level.

\section{TABLES 7 AND 8 AROUND HERE}

The change in immigration is instrumented by means of (9), and immigrants are defined, respectively, as born abroad (column 1), born outside Europe (column 3), and foreign nationals (column 5). The relative first stage regressions are displayed, respectively, in columns 2,4 and 6.

All 2SLS estimates include analogous controls as in previous fixed effects estimations and are equivalent to limited information maximum likelihood (LIML) estimates since the model is just-identified. In all cases the instrument is positively and significantly correlated with the immigration measure, and the effect of immigration on crime victimization is never significant, confirming the empirical findings of the previous sections. The point estimates are close to the SSIV estimate excluding those small regions where the sampling error in the ESS immigration share is likely to be large (i.e. whose cell size is lower than 100, as in column 3 of Table 6).

The F-test statistic of excluded instruments is always in the order of 20, i.e. relatively safe as regards weak instruments (Bound, Jaeger, and Baker, 1995). In addition, in presence of weak instruments, the bias increases with the number of instruments whereas our just-identified IV model is median unbiased and it is therefore likely to be immune from the weak instrument problem. Nevertheless the table reports the p-values of two structural parameter tests that are robust to weak instruments. The first is the Anderson - Rubin (AR) test (Anderson and Rubin, 1949) and the second is the Conditional Likelihood Ratio (CLR) test proposed by Moreira (2003) that has been shown to outperform the AR test in power simulations (Andrews, Moreira, and Stock, 2006). Both tests indicate that the effect of immigration on crime victimization is 
not statistically significant.

Table 8 displays similar regressions for crime perception. In this case we find large and significant effects on crime perception when the latter is measured by the the proportion of respondents who feel very unsafe when walking alone after dark. No significant effect is found when considering crime perception as measured by citizens feeling unsafe. ${ }^{12}$.

\subsection{Crime and Attitude Toward Immigration}

Our results suggest that immigration has no significant effect on crime victimization in Western Europe and the result is robust across all identification strategies presented above. We do find however that an increase in immigration induces an increase in the share of those natives who feel very unsafe, when adopting an IV specification. In other words, our IV findings suggest that despite crimes do not increase with immigration, still the fear of crime increases with it, especially among those natives who fear crime the most.

How do these findings relate to the attitude toward immigration in Europe? Figure 4 summarizes the attitude toward immigrants across European regions, as measured by the average score assigned by natives to the question concerning whether immigrants make the host country a worse or a better place to live (from worse to better). Sweden, Denmark, Finland, Poland, Ireland, and Eastern Spain (Cataluna) are very pro-immigrant regions. In Germany there is a clear divergence between the West and the East, with eastern Germany being significantly less positive about immigration than the West.

\section{FIGURE 4 AROUND HERE}

Both crime victimization and crime perception are significantly correlated with the attitude of natives toward immigrants. Table 9 provides some empirical evidence considering two measures of attitude that can be affected by crime victimization and fear. The dependent variable in columns (1) and (3) reflects the same indicator used in the figure, i.e. whether respondents believe that immigrants make the country worse (the variable is a dummy equal to 1 for respondents who answer 0-4 on a scale from 0 to 10, from worse to better, and zero otherwise). The

\footnotetext{
${ }^{12}$ Note that the number of observations is slightly smaller with respect to Table 6 because in some cases the share of respondents feeling very unsafe is zero and therefore those observations are dropped from the sample when we take logs. However, consistently with our findings, no significant effect of immigration is found on the log change in crime victimization and the share of those respondents who feel unsafe on such smaller sample.
} 
dependent variable in columns (2) and (4) indicates whether respondents believe that many or some (as opposed to few or no) immigrants from developing countries outside Europe should be allowed to come to the country to live.

\section{TABLE 9 AROUND HERE}

The regressions are estimated on individual data controlling for age, gender, labour market status, educational attainment, degree of urbanization of local residence and whether the respondent identifies with the political right (i.e. whether the score assigned to a left to right scale from 0 to 10 is greater than 5).

All models point to a significant and positive correlation of crime victimization and perception with the belief that immigrants make the country a worse place to live. However the estimated coefficient of crime perception is much larger than the coefficient of crime victimization. According to the model in column 1, feeling unsafe is associated with a 12.4 percentage points increase in the probability that one sees immigration as making the country worse, versus the 1.2 percentage point increase associated with being an actual crime victim in the past 5 years. Similar findings are obtained when the dependent variable is the attitude toward opening the country to immigrants who come from developing countries outside Europe. Here feeling unsafe is associated with a 7.5 percentage points increase in the probability that a native is against allowing immigrants to live in the country versus a 1 percentage point increase associated with being an actual crime victim. The empirical findings are robust to different specifications (i.e. differentiating between individuals who feel unsafe or very unsafe and using data collapsed at the regional level, not reported) and to the separate inclusion of crime victimization and perception (not reported). In addition, the immigration share is never statistically significant when included.

We also find that the probability to have a negative attitude toward immigration increases when natives are unemployed (by around 3 percentage points) and on the right of the political spectrum (by around 10 percentage points). In addition, the attitude worsens when respondents are male, older, with low education and living in rural areas. ${ }^{13}$

\footnotetext{
${ }^{13}$ For further evidence on the determinants of attitude toward immigration see Mayda (2006); O'Rourke and Sinnott (2006); Dustmann and Preston (2007); Hainmueller and Hiscox (2010); D'Hombres and Nunziata (2014).
} 
These results do not point necessarily to a causal effect from crime victimization and perception to the attitude towards immigrants, as we cannot exclude that unobservable factors at the individual level may explain them. Still, the absence of a causal effect of immigration on crime victimization pointed out in the previous sections is at odds with the estimated causal effect of immigration on crime perception and with the strong and robust correlation between crime perception and the natives' attitude toward immigration.

Our findings may be partly explained by the cross-sectional correlation between immigration and crime displayed in Tables 3 and 4. The public perception of the effect of immigration on crime may be misled by the observation that regions with higher immigrant penetration are generally those characterized by higher crime victimization but failing to impute such correlation to unobserved third factors and to distinguish correlation from causation. However, the cross-sectional correlation is too low to explain these findings fully.

Further research is therefore needed in order to clarify why natives associate immigration with crime despite a lack of robust empirical evidence supporting such association, at least in western Europe. Previous studies, such as Fitzgerald, Curtis, and Corliss (2012), show how the concern about immigration in Germany is stronger in election years. This suggests that the public perception of the consequences of immigration in host societies may be strongly influenced by media stereotypes about immigrants and by local political opportunism.

\section{Concluding Remarks}

This paper presents the first attempt to investigate the empirical relationship between immigration and crime victimization and perception patterns by exploiting the immigration waves that took place in the 2000s in western Europe.

Individual crime victimization and crime perception data from the European Social Survey (ESS) is matched with measures of immigration penetration in European regions from the Eurostat Labour Force Survey (LFS) in order to estimate the effect of changes in immigration on crime victimization rates and on the subjective representation of criminality in local areas of residence. The sample is constituted of individual-level repeated cross-sectional data collected in sixteen western European countries in four waves of the ESS every two years from 2002 to 2008. This timeframe was characterized by large immigration inflows for most western 
European countries.

The major difficulties in the analysis are sampling error and omitted variable bias. First, regional immigration shares may be mismeasured when calculated using survey data because the region/year cell size may be too small. Second, the location of immigrants across European regions may be endogenous.

We adopt and discuss three alternative research strategies to deal with sampling error and omitted variable bias and we provide a set of Monte Carlo simulations in order to investigate the extent of the attenuation bias that may be induced by sampling error.

Our first specification controls for region- and country-specific time fixed effects. This is the most restrictive strategy since we are able to estimate the causal effect of immigration on individual crime victimization and crime perception only assuming that omitted factors are accounted for by fixed effects. Our Monte Carlo simulations show that, given the large size of the region/year cells in LFS data, these set of estimates should be affected by a small attenuation bias. However, we should be able to identify a significant, albeit biased, effect of immigration on crime if present.

Our second approach consists in assuming a more general random error in the immigration penetration measure, so that we can instrument migration measured with ESS data using a second independent measurement from LFS data. Assuming both measures are affected by sampling error and that they are correlated with the unobservable true measure of regional immigration, we may use one measurement as instrument for the other since the two errors are independent. This split-sample IV strategy (SSIV) is shown to drastically reduce the attenuation bias induced by sampling error in Monte Carlo simulations. However, omitted factors are still accounted for by fixed effects.

Finally, we provide a set of IV estimates in a specification in differences by instrumenting migration using exogenous supply-push changes in immigration patterns that accounts for both measurement error and omitted variable bias. This is the most general approach, in which both measurement errors and omitted time-varying factors are addressed. Our Monte Carlo simulations show how such model in differences is not affected by any attenuation bias induced by spurious changes in victimization rates when the average region/year cell size is small.

The empirical results are robust across the three specifications and they consistently point to a statistically not-significant effect of immigration on individual crime victimization in des- 
tination regions when we control for unobservable regional characteristics. Immigration is characterized by a significant, although small, positive correlation with crime only when we exclude the regional fixed effects from the linear probability model. In other words, the correlation between immigration and crime is likely to be caused by unobservable factors at the regional level. In addition, the analysis provides some evidence of a link between immigration and crime perception (or crime fear).

Our findings seem to suggest a misconception of the link between immigration and crime among European natives that is reflected in crime perception being strongly associated with a negative attitude toward immigrants. The public perception of the effect of immigration on crime may be partly misled by the casual empirical evidence available to the public. Natives may observe that areas where immigrants are more prevalent are also generally those characterized by higher crime rates, failing to impute such correlation to unobserved third factors and to distinguish correlation from causation. However, the cross-sectional correlation between immigration and crime is small, suggesting that other factors previously investigated by the literature may generate such a bias against immigration, including the media's misrepresentation of the immigration phenomenon and political opportunism.

Our empirical findings call for a better public assessment of the immigration phenomenon in western Europe, especially as regards its implications in terms of criminality, and for a more transparent approach to the discussion about the costs and benefits of immigration in host countries. 


\section{References}

Anderson, T. W., And H. Rubin (1949): "Estimators of the Parameters of a Single Equation in a Complete Set of Stochastic Equations.," Annals of Mathematical Statistics, 21, 570-582. $4.5,7,8$

Andrews, D. W. K., M. J. Moreira, And J. H. Stock (2006): "Optimal Two-Sided Invariant Similar Tests for Instrumental Variables Regression," Econometrica, 74(3), 715752. $4.5,7,8$

Angrist, J., And W. Evans (1998): "Children and Their Parents Labor Supply: Evidence from Exogenous Variation in Family Size," American Economic Review, 88, 450-477. 8

Angrist, J. D., And A. B. Krueger (1995): "Split-Sample Instrumental Variables Estimates of the Return to Schooling," Journal of Business $\& 3$ Economic Statistics, 13(2), 225-35. 3.3

Aydemir, A., And G. J. BorJas (2011): "Attenuation Bias in Measuring the Wage Impact of Immigration," Journal of Labor Economics, 29(1), 69-113. 1, 3.1, 4.2

Bauer, T., And K. F. Zimmermann (1999): "Assessment of Possible Migration Pressure and its Labour Market Impact Following EU Enlargement to Central and Eastern Europe," IZA Research Reports 3, Institute for the Study of Labor (IZA). 3.1

Becker, G. S. (1968): "Crime and Punishment: An Economic Approach," Journal of Political Economy, 76, 169. 1

Bell, B., S. Machin, and F. Fasani (2010): "Crime and Immigration: Evidence from Large Immigrant Waves," IZA Discussion Papers 4996, Institute for the Study of Labor (IZA). 2, 3.4

Bianchi, M., P. Buonanno, and P. Pinotti (2008): "Immigration and crime: an empirical analysis," Temi di discussione (Economic working papers) 698, Bank of Italy, Economic Research Department. 2, 3.2, 3.4

Boeri, T. (2010): "Immigration to the Land of Redistribution," Economica, 77(308), 651-687. $1,4.1$ 
BorJAs, G. (1999): "The economic analysis of immigration," in Handbook of Labor Economics, ed. by O. Ashenfelter, and D. Card, pp. 1679-1760. Elsevier, Amsterdam. 1

BorJAs, G. J. (1994): "The economics of immigration," Journal of economic Literature, 32, 1668-1717. 1

Borjas, G. J., J. Grogger, and G. H. Hanson (2010): "Immigration and the Economic Status of African-American Men," Economica, 77, 255-282. 1

Bound, J., D. Jaeger, And R. BAKer (1995): "Problems With Instrumental Variables Estimation When The Correlation Between The Instruments And The Endogenous Explanatory Variable Is Weak," Journal of the American Statistical Association, 90, 443-450. 4.5

Buonanno, P., F. Drago, R. Galbiati, and G. Zanella (2011): "Crime in Europe and the United States: dissecting the reversal of misfortunes," Economic Policy, 26(67), 347-385. 4.1

Butcher, K. F., And A. M. Piehl (1998): "Cross-city evidence on the relationship between immigration and crime," Journal of Policy Analysis and Management, 17, 457-493. 2

(2007): "Why are Immigrants' Incarceration Rates so Low? Evidence on Selective Immigration, Deterrence, and Deportation," NBER Working Papers 13229, National Bureau of Economic Research, Inc. 2

Card, D. (2001): "Immigrant Inflows, Native Outflows, and the Local Labor Market Impacts of Higher Immigration," Journal of Labor Economics, 19(1), 22-64. 3.1, 3.4

Card, D., C. Dustmann, and I. Preston (2009): "Immigration, Wages, and Compositional Amenities," NBER Working Papers 15521, National Bureau of Economic Research, Inc. 1

D'Hombres, B., and L. Nunziata (2014): "Wish You Were Here? Quasi-Experimental Evidence on the Effect of Education on Attitude Towards Immigrants," mimeo, University of Padua. 13

Durbin, J. (1954): "Errors in Variables," Review of the International Statistical Institute, 22, 23-32. 3.3 
Dustmann, C., T. Frattini, and I. P. Preston (2008): "The Effect of Immigration along the Distribution of Wages," CReAM Discussion Paper Series 0803, Centre for Research and Analysis of Migration (CReAM), Department of Economics, University College London. 3.4

Dustmann, C., And I. P. Preston (2007): "Racial and Economic Factors in Attitudes to Immigration," The B.E. Journal of Economic Analysis and Policy, 7(1). 13

Eurostat (2012): Statistics in Focus: Crime and Criminal Justice. Eurostat. 4.1

Fitzgerald, J., K. A. Curtis, and C. L. Corliss (2012): "Anxious Publics: Worries over crime and immigration," Comparative Political Studies, 45, 477-506. 2, 4.6

Freeman, R. (1999): "The Economics of Crime," in Handbook of Labor Economics, ed. by O. C. Ashenfelter, and D. Card, vol. 3, pp. 3529-3571. Elsevier. 1

Griliches, Z., And W. M. Mason (1972): "Education, Income, and Ability," Journal of Political Economy, University of Chicago Press, 80(3), S74-S103. 3.3

Hainmueller, J., And M. J. Hiscox (2010): "Attitudes toward Highly Skilled and Lowskilled Immigration: Evidence from a Survey Experiment," American Political Science Review, 104, 61-84. 13

Hale, C. (1996): "Fear of crime: A review of the literature," International Review of Victimology, 4, 79-150. 2

Jackson, J., And M. Stafford (2009): "Public Health and Fear of Crime: A Prospective Cohort Study," British Journal of Criminology, 49, 832-847. 2

Kessler, R., And E. Wethington (1991): "The reliability of life event reports in a community survey," Psychological Medicine, 21, 723-738. 4.1

Lauritsen, J. L., And M. L. Rezey (2013): Measuring the Prevalence of Crime with the National Crime Victimization Survey. Technical Report, U.S. Department of Justice, Office of Justice Programs, Bureau of Justice Statistics. 4.1

Lee, M. T., R. Martinez, and R. Rosenfeld (2001): "Does Immigration Increase Homicide? Negative Evidence From Three border Cities," The Sociological Quarterly, 42(4), 559580. 2 
Lemos, S., And J. Portes (2008): "New Labour? The Impact of Migration from Central and Eastern European Countries on the UK Labour Market," IZA Discussion Papers 3756, Institute for the Study of Labor (IZA). 3.4

Levine, J. P. (1976): "The Potential For Crime Overreporting In Criminal Victimization Surveys," Criminology, 14(3), 307-330. 4.1

Mastrobuoni, G., and P. Pinotti (2010): "Migration Restrictions and Criminal Behavior: Evidence from a Natural Experiment," paper presented at the CSEA 2010 workshop on migration. 2

MAYdA, A. (2006): "Who Is Against Immigration? A Cross-Country Investigation of Individual Attitudes toward Immigrants," The Review of Economics and Statistics, 88(3), 510-530. 13

Moehling, C., And A. M. Piehl (2007): "Immigration and Crime in Early 20th Century America," NBER Working Papers 13576, National Bureau of Economic Research, Inc. 2

MoreirA, M. J. (2003): “A Conditional Likelihood Ratio Test for Structural Models," Econometrica, 71(4), 1027-1048. 4.5, 7, 8

Munshi, K. (2003): "Networks In The Modern Economy: Mexican Migrants In The U.S. Labor Market," The Quarterly Journal of Economics, 118(2), 549-599. 3.4

O'Rourke, K. H., And R. Sinnott (2006): "The determinants of individual attitudes towards immigration," European Journal of Political Economy, 22(4), 838-861. 13

Reiersol, O. (1941): "Confluence analysis by means of lag moments and other methods of confluence analysis," Econometrica, 9, 1-24. 3.3

SpenkuCH, J. (2011): "Understanding the impact of immigration on crime," University of Chicago, unpublished. 2

Strube, G. (1987): "Answering Survey Questions: The Role of Memory," in Social Information Processing and Survey Methodology, ed. by H. Hippler, N. Schwarz, and S. Sudman, New York. Springer. 4.1 
United States Department of Justice, F. B. o. I. (2011): Crime in the United States 2010. United States Department of Justice, Federal Bureau of Investigation. 4.1 
Figure 1: Victims of burglary or assault in the last five years in Europe as percentage of resident population in Europe

\section{Crime Victims as \% of resident population in Europe}

Source: Eurostat Social Survey, 2002-2008

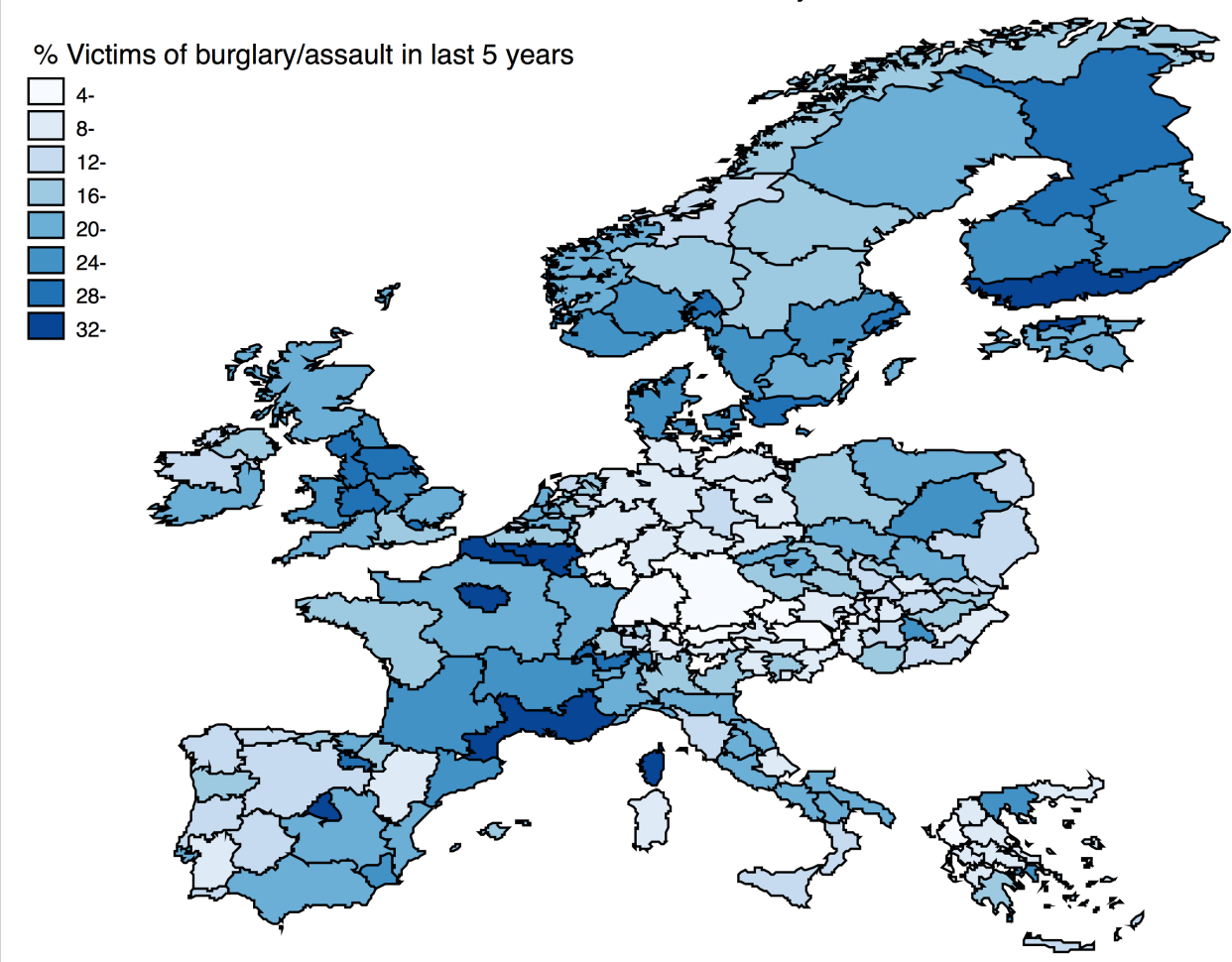

Note: the figure is drawn by the author using data from the European Social Survey from 2002 to 2008. Regions are NUTS 2 level. 
Figure 2: Percentage of respondents feeling "safe" or "very safe" when walking alone after dark in local area

\section{Feeling Safe as \% of resident population in Europe \\ Source: Eurostat Social Survey, 2002-2008}

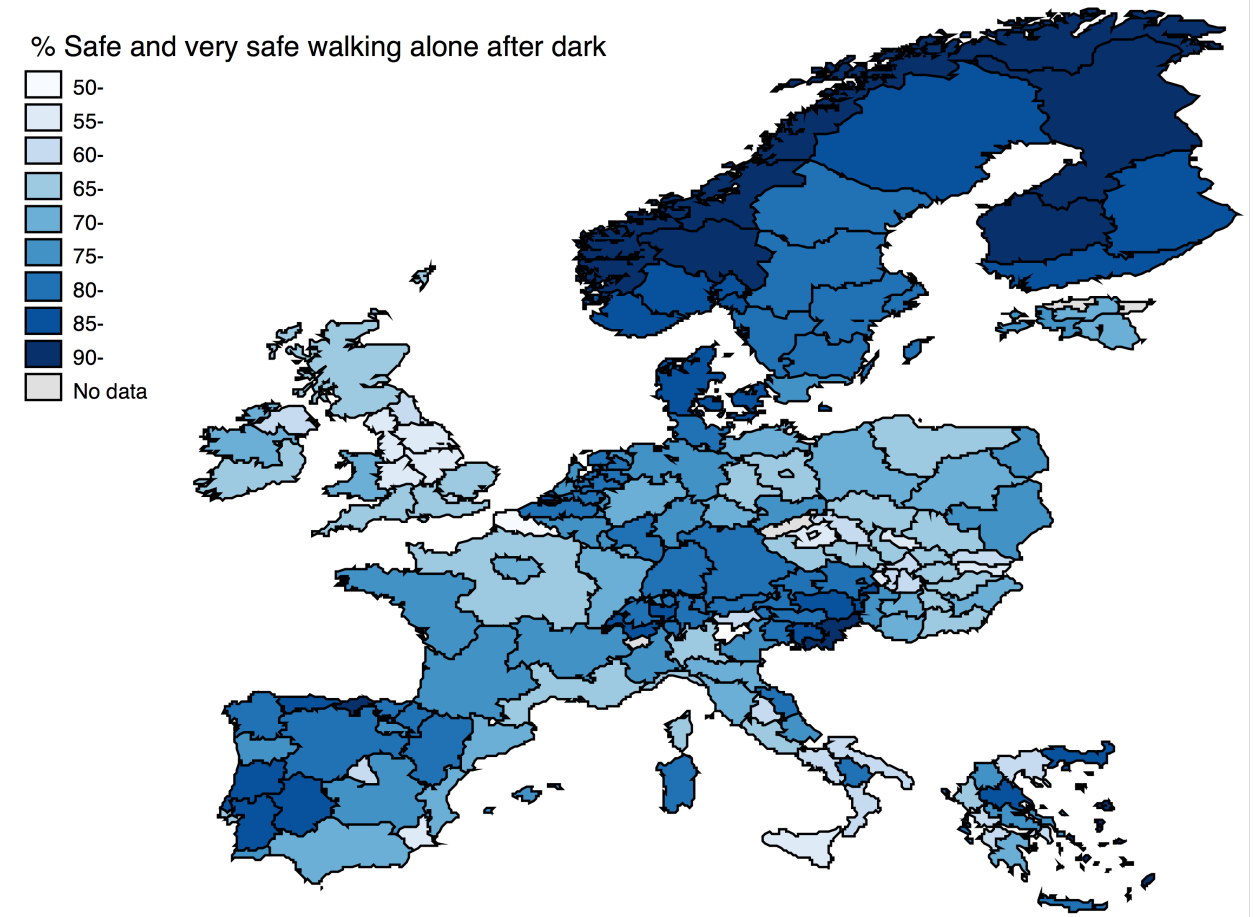

Note: the figure is drawn by the author using data from the European Social Survey from 2002 to 2008. Regions are NUTS 2 level. 
Figure 3: Immigrants (born abroad) as percentage of resident population in Europe

\section{Immigrants as \% of resident population in Europe}

Source: Eurostat Labour Force Survey

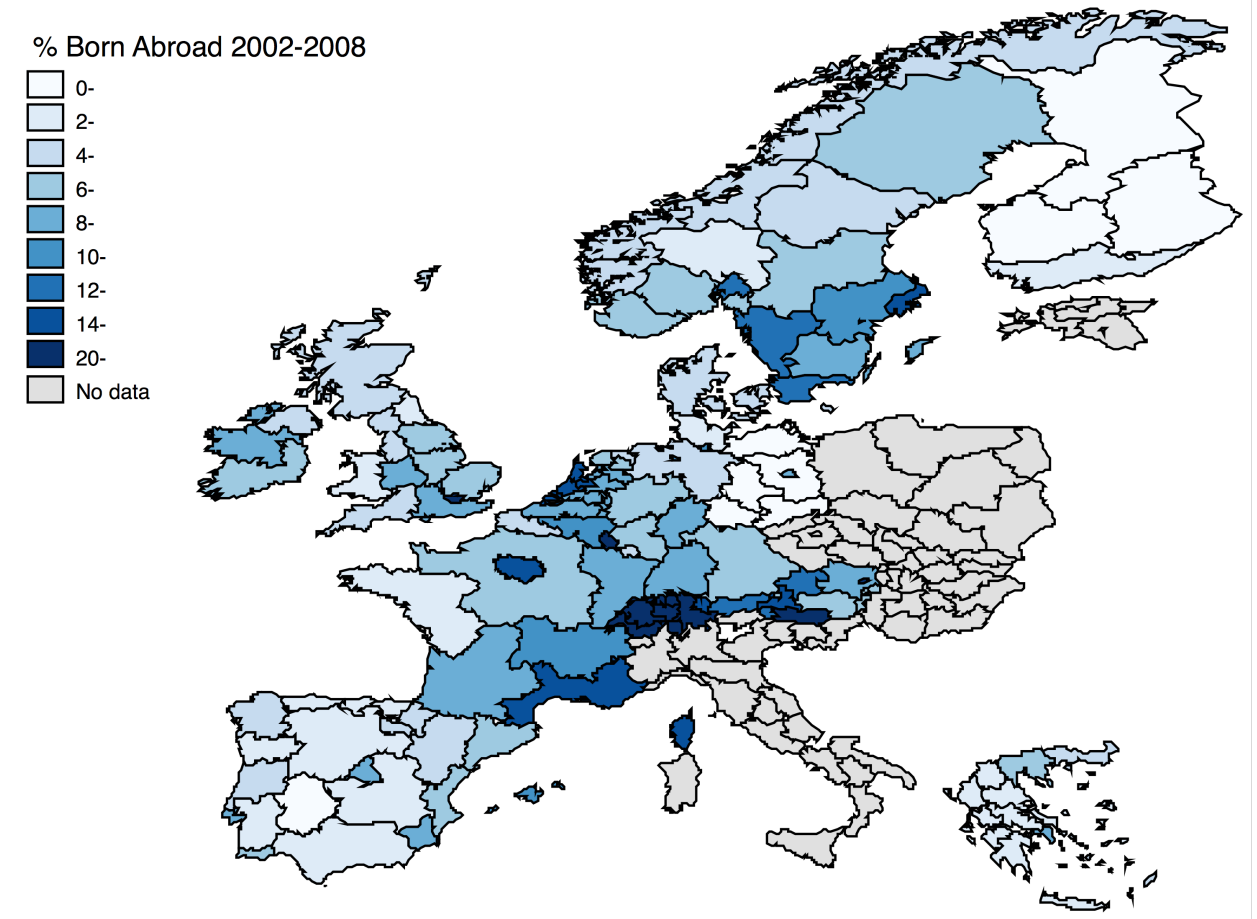

Note: figures are drawn by the author using data from the Eurostat European Labour Force Survey from 2002 to 2008. 
Figure 4: Average score to question "Is country made a worse or better place to live by people coming to live here from other countries?", where answer can go from 0 (worse) to 10 (better)

\section{Immigrants make country worse or better place to live \\ ESS}

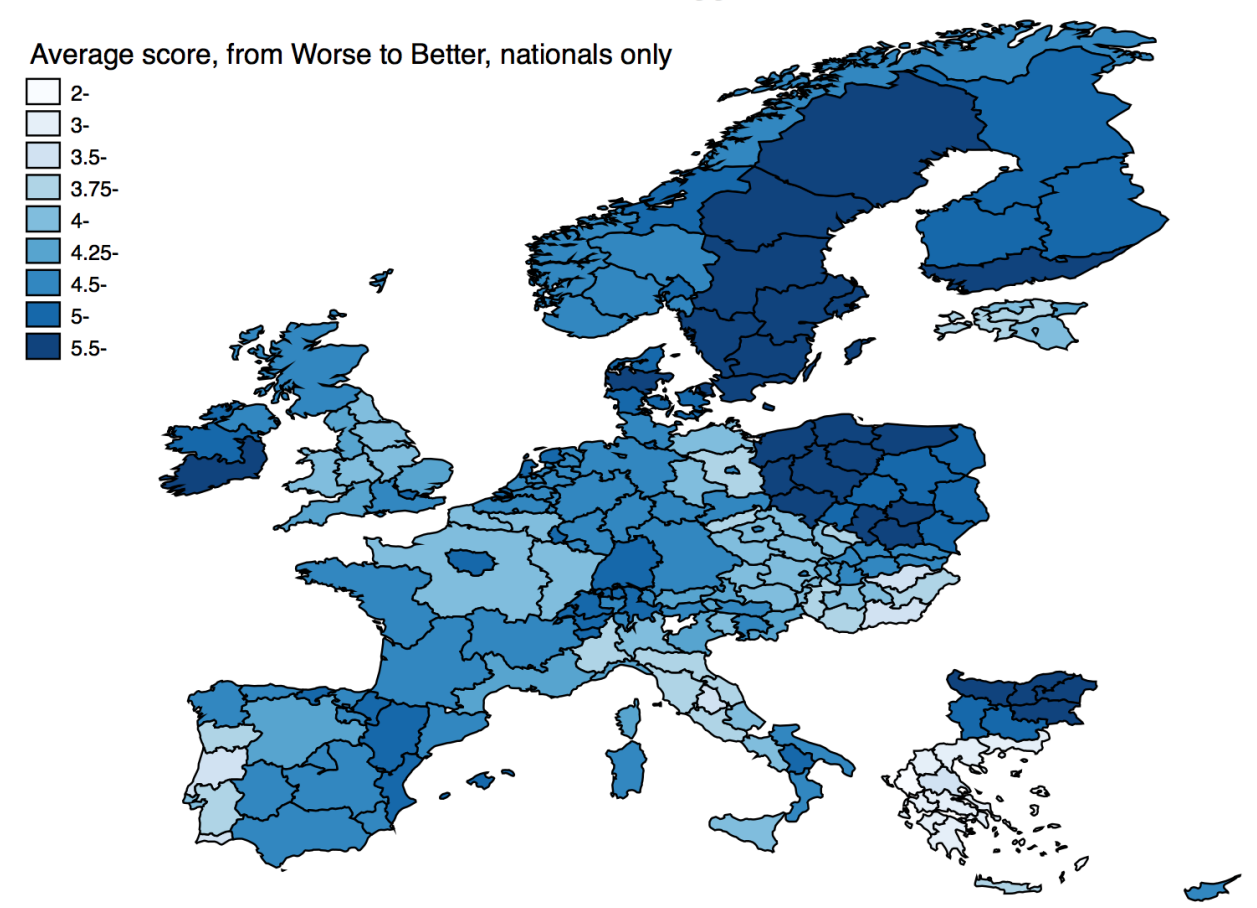

Note: the figure is drawn by the author using data from the European Social Survey from 2002 to 2008. Regions are NUTS 2 level. 


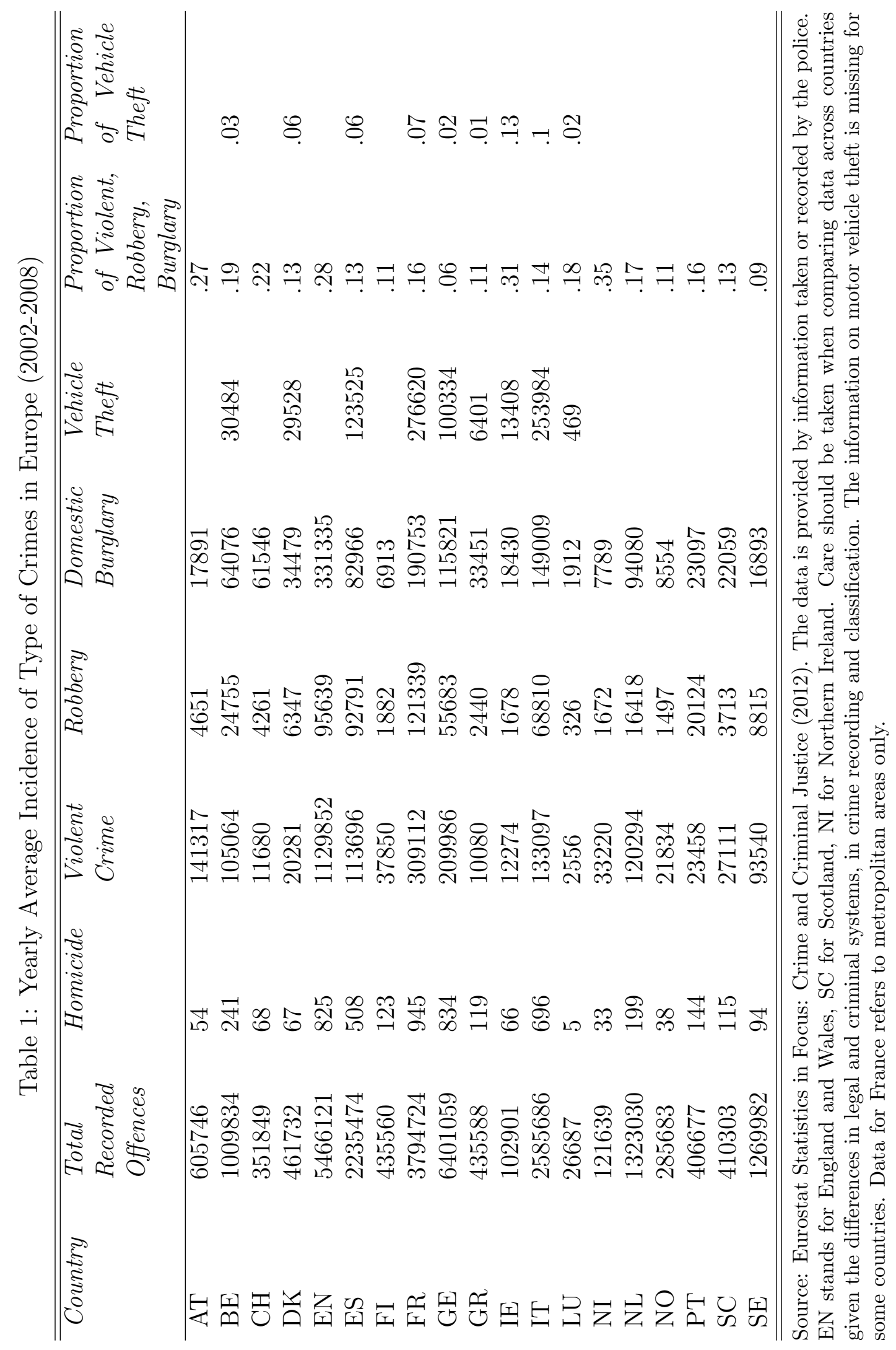


Table 2: Monte Carlo Simulations of Fixed Effects and SSIV Models by sampling rate

\begin{tabular}{lccccccc}
\hline Sampling rate & $1 / 1000$ & $3 / 1000$ & $5 / 1000$ & $1 / 100$ & $3 / 100$ & $5 / 100$ & $10 / 100$ \\
\hline Cell size & 104 & 313 & 522 & 1043 & 3130 & 5216 & 10433 \\
$\hat{\beta}_{\text {popul }}^{F E}$ & 1 & .998 & 1.001 & .999 & .999 & 1 & 1 \\
s.e. $\left(\hat{\beta}_{\text {popul }}^{F E}\right)$ & .02 & .011 & .009 & .006 & .004 & .003 & .002 \\
$\hat{\beta}_{\text {sample }}^{F E}$ & .153 & .356 & .483 & .65 & .851 & .909 & .953 \\
s.e. $\left(\hat{\beta}_{\text {sample }}^{F E}\right)$ & .008 & .007 & .006 & .005 & .003 & .003 & .002 \\
$\hat{\beta}_{\text {sample } 1 / 1000}^{I V}$ & 1.053 & 1.089 & 1.012 & 1.041 & 1.025 & 1.006 & 1.026 \\
s.e. $\left(\hat{\beta}_{\text {sample } 1 / 1000}^{I V}\right)$ & .081 & .025 & .015 & .01 & .005 & .003 & .002 \\
$\hat{\beta}_{\text {sample } 3 / 1000}^{I V}$ & 1.001 & 1.03 & 1.024 & .994 & 1.002 & .992 & 1.013 \\
s.e. $\left(\hat{\beta}_{\text {sample } 3 / 1000}^{I V}\right)$ & .055 & .021 & .014 & .008 & .004 & .003 & .002 \\
$\hat{\beta}_{\text {sample 5/1000 }}^{I V}$ & 1.003 & .995 & 1.008 & 1.001 & 1.01 & 1.009 & 1.001 \\
s.e. $\left(\hat{\beta}_{\text {sample } 5 / 1000}^{I V}\right)$ & .054 & .02 & .013 & .008 & .004 & .003 & .002 \\
$\hat{\beta}_{\text {sample } 1 / 100}^{I V}$ & .998 & 1.007 & 1.023 & 1 & 1.004 & 1 & .996 \\
s.e. $\left(\hat{\beta}_{\text {sample } 1 / 100}^{I V}\right)$ & .053 & .02 & .013 & .008 & .004 & .003 & .002 \\
Avg $\frac{\text { Imm }}{\text { Pop }}$ popul & .137 & .137 & .137 & .137 & .137 & .137 & .137 \\
Avg $\frac{\text { Imm }}{\text { Pop }}$ sample & .137 & .138 & .137 & .137 & .137 & .137 & .137 \\
\hline
\end{tabular}

Monte Carlo simulations of Fixed Effects and SSIV model varying the sampling rate (i.e. the average number of observations per region/year cell) used to calculate immigration shares from a population of 10 millions individuals. All reported statistics are averages across 500 replications of random samples at the given sampling rate. The table reports the average cell size; the estimated fixed effects coefficient and standard error of immigration when observing the true regional immigration shares at the population level; the estimated fixed effects coefficient and standard error of immigration when immigration shares are calculated from sample, at different sampling rates (by column); the estimated SSIV coefficient and standard error of immigration for different sampling rates of the sample used to derive the instrumented immigration share (by row); the true average immigration share at the population level and the average immigration share in each sample. 
Table 3: Linear probability models of crime victimization

\begin{tabular}{lcccc}
\hline VARIABLES & $\begin{array}{c}(1) \\
\text { crimevictim }\end{array}$ & $\begin{array}{c}(2) \\
\text { crimevictim }\end{array}$ & $\begin{array}{c}(3) \\
\text { crimevictim }\end{array}$ & $\begin{array}{c}(4) \\
\text { crimevictim }\end{array}$ \\
\hline $\log (\mathrm{IMM} / \mathrm{POP})$ & $0.045^{* * *}$ & $0.028^{* * *}$ & 0.029 & 0.030 \\
& $(0.010)$ & $(0.008)$ & $(0.024)$ & $(0.025)$ \\
& & & & \\
Observations & 101,738 & 101,738 & 101,738 & 101,738 \\
R-squared & 0.042 & 0.051 & 0.053 & 0.060 \\
Regional FE & NO & NO & YES & YES \\
Other Ind. Level Controls & NO & YES & NO & YES \\
Demographic Controls & YES & YES & YES & YES \\
Country X Year FE & YES & YES & YES & YES \\
Clustered SE & YES & YES & YES & YES \\
\hline
\end{tabular}

Robust standard errors in parentheses

$$
\text { *** } \mathrm{p}<0.01,{ }^{*} * \mathrm{p}<0.05,{ }^{*} \mathrm{p}<0.1
$$

Dependent variable is whether the respondent or a household member has been the victim of assault or burglary in the previous five years. Immigration is defined as the regional share of individuals born abroad (in logs) and it is calculated from LFS data over the previous five years. The countries covered by the data are AT, BE, CH, DE, DK, ES, FI, FR, GR, IE, LU, NL, NO, PT, SE and UK. Regional and country-specific year fixed effects are included. Controls include educational attainment, degree of urbanization of local area, gender, age, age squared, and if main source of income is financial. Standard errors are clustered by regions. 


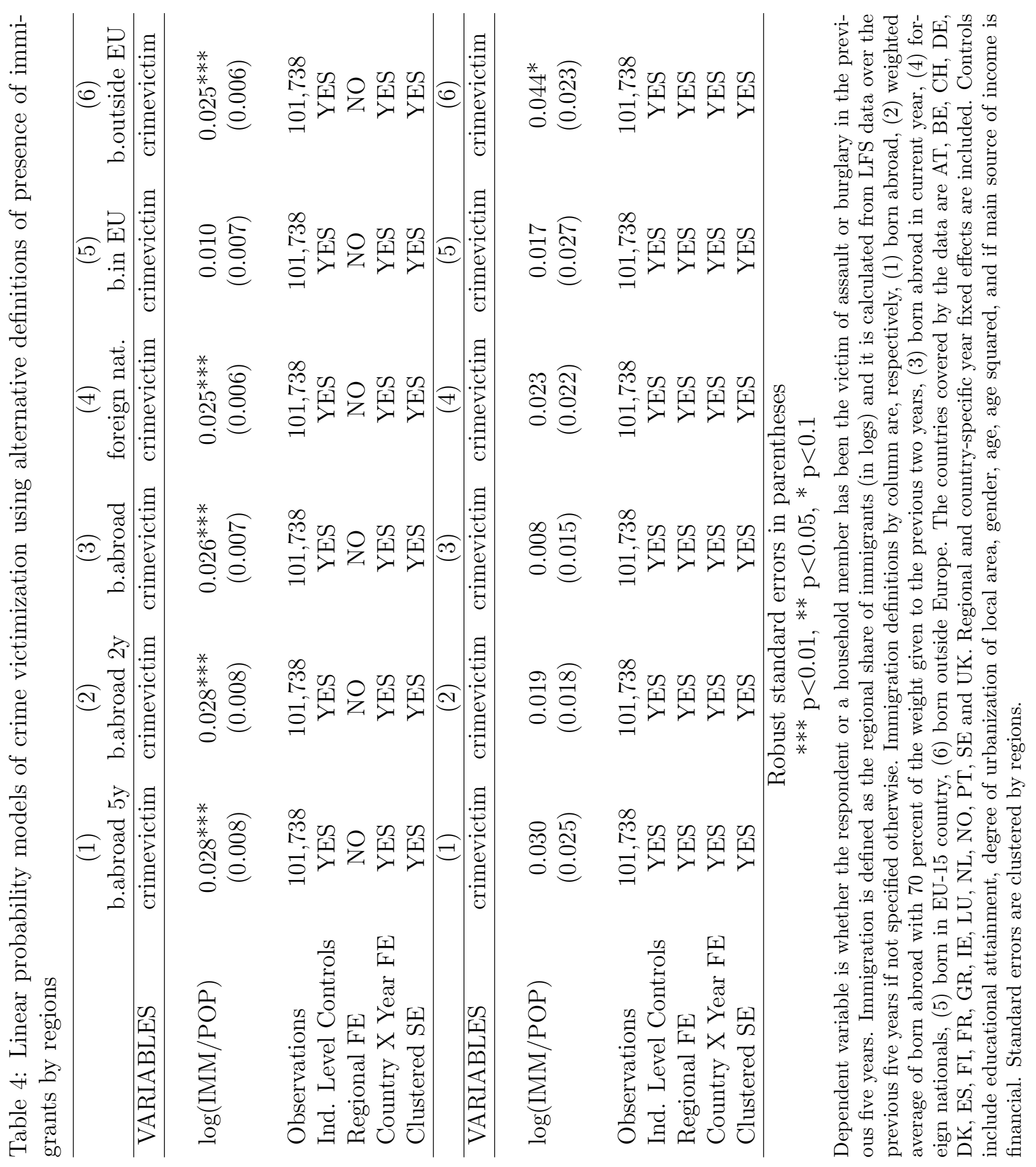


Table 5: Linear probability models of crime perception

\begin{tabular}{lcccc}
\hline & $(1)$ & $(2)$ & $(3)$ & $(4)$ \\
VARIABLES & unsafe & unsafe & unsafe & unsafe \\
\hline $\log (\mathrm{IMM} / \mathrm{POP})$ & $0.024^{* *}$ & 0.007 & -0.014 & -0.012 \\
& $(0.011)$ & $(0.009)$ & $(0.012)$ & $(0.013)$ \\
& & & & \\
\hline & $(1)$ & $(2)$ & $(3)$ & $(4)$ \\
VARIABLES & very unsafe & very unsafe & very unsafe & very unsafe \\
\hline & & & & \\
$\log ($ IMM/POP) & 0.006 & 0.002 & 0.005 & 0.006 \\
& $(0.004)$ & $(0.004)$ & $(0.009)$ & $(0.009)$ \\
Observations & & & & \\
R-squared & 101,942 & 101,942 & 101,942 & 101,942 \\
Regional FE & 0.102 & 0.123 & 0.116 & 0.135 \\
Other Ind. Level Controls & NO & NO & YES & YES \\
Demographic Controls & NO & YES & NO & YES \\
Country X Year FE & YES & YES & YES & YES \\
Clustered SE & YES & YES & YES & YES \\
\hline
\end{tabular}

Robust standard errors in parentheses

$$
\text { *** } \mathrm{p}<0.01,{ }^{*} * \mathrm{p}<0.05,{ }^{*} \mathrm{p}<0.1
$$

Dependent variable is whether respondent feels unsafe or very unsafe when walking alone after dark. Immigration is defined as the current regional share of individuals born abroad (in logs) and it is calculated from LFS data. The countries covered by the data are AT, BE, CH, DE, DK, ES, FI, FR, GR, IE, LU, NL, NO, PT, SE and UK. Regional and country-specific year fixed effects are included. Controls include educational attainment, degree of urbanization of local area, gender, age, age squared, and if main source of income is financial. Standard errors are clustered by regions. 
Table 6: Split Sample IV linear probability models of crime victimization

\begin{tabular}{lccccc}
\hline & $\begin{array}{c}(1) \\
\text { b.abroad }\end{array}$ & $\begin{array}{c}(2) \\
\text { b.abroad }\end{array}$ & $\begin{array}{c}(3) \\
\text { b.abr. c.size }>100\end{array}$ & $\begin{array}{c}(4) \\
\text { foreign nat. }\end{array}$ & $\begin{array}{c}(5) \\
\text { b.outside EU }\end{array}$ \\
\hline VARIABLES & crimevictim & crimevictim & crimevictim & crimevictim & crimevictim \\
\hline $\log (\mathrm{IMM} /$ POP $)$ & $0.031^{* * *}$ & 0.054 & 0.198 & 0.009 & 0.037 \\
& $(0.008)$ & $(0.165)$ & $(0.655)$ & $(0.042)$ & $(0.111)$ \\
Observations & & & & & \\
R-squared & 101,560 & 101,560 & 95,849 & 98,017 & 101,176 \\
Regional FE & 0.051 & 0.059 & 0.049 & 0.060 & 0.059 \\
Country X Year FE & NO & YES & YES & YES & YES \\
Clustered SE & YES & YES & YES & YES & YES \\
First Stage Beta & 0.819 & 0.125 & YES & YES & YES \\
First Stage SE & 0.002 & 0.008 & 0.096 & 0.311 & 0.134 \\
\hline
\end{tabular}

Robust standard errors in parentheses

$$
\text { *** } \mathrm{p}<0.01,{ }^{*} * \mathrm{p}<0.05,{ }^{*} \mathrm{p}<0.1
$$

Split sample IV regressions, instrumenting immigration shares calculated from ESS data with immigration shares calculated from LFS data. Dependent variable is whether the respondent or a household member has been the victim of assault or burglary in the previous five years. Immigration is defined as the regional share of born abroad immigrants (in logs) in all columns except in column (4) that refers to foreign nationals and (5) that refers to born outside Europe. Column (3) restricts the estimations to those regions where the region/year cell size in ESS data is larger than 100. The countries covered by the data are AT, BE, CH, DE, DK, ES, FI, FR, GR, IE, LU, NL, NO, PT, SE and UK. Regional and country-specific year fixed effects are included. Controls include educational attainment, degree of urbanization of local area, gender, age, age squared, and if main source of income is financial. Standard errors are clustered by regions. 


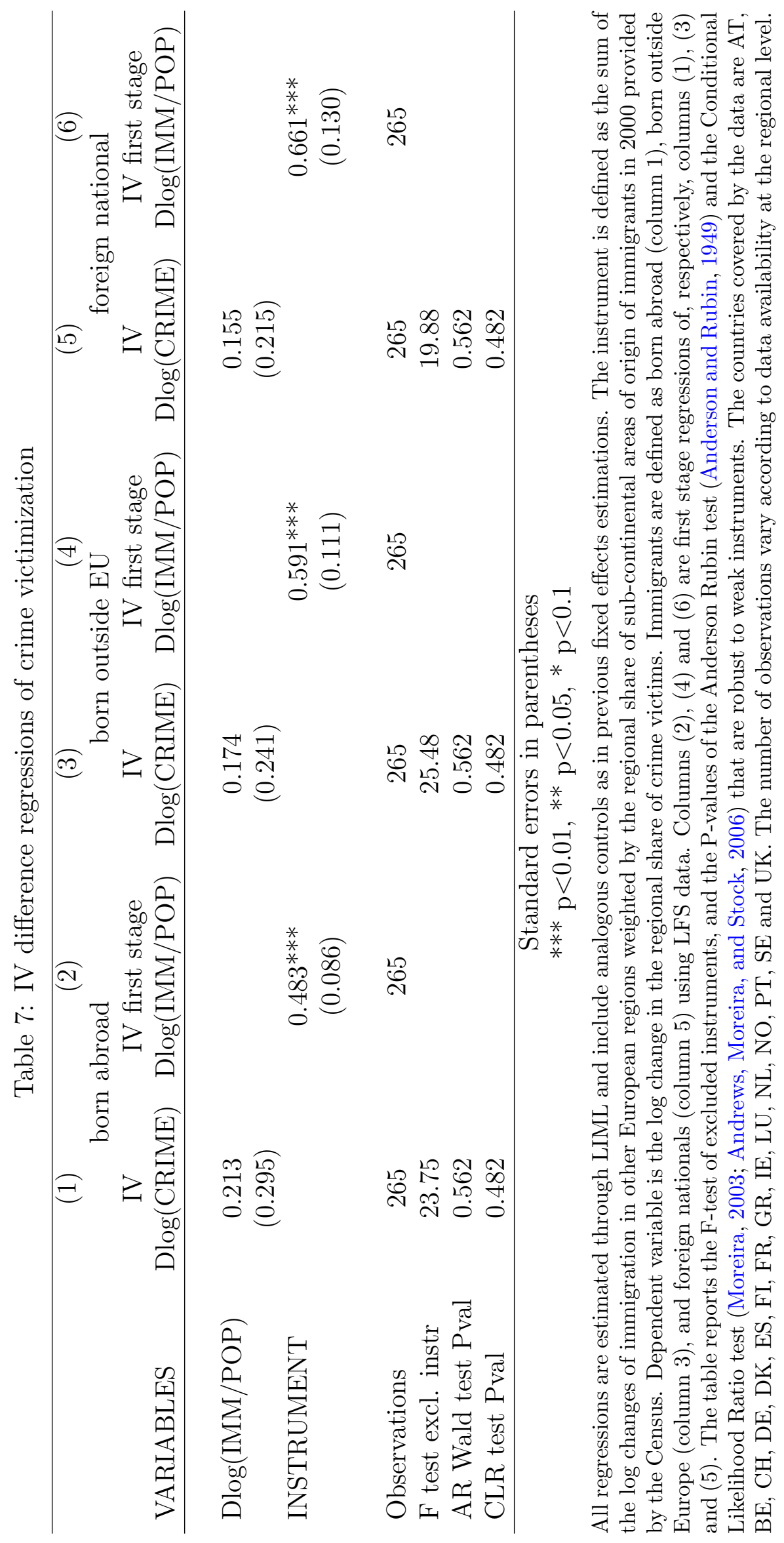




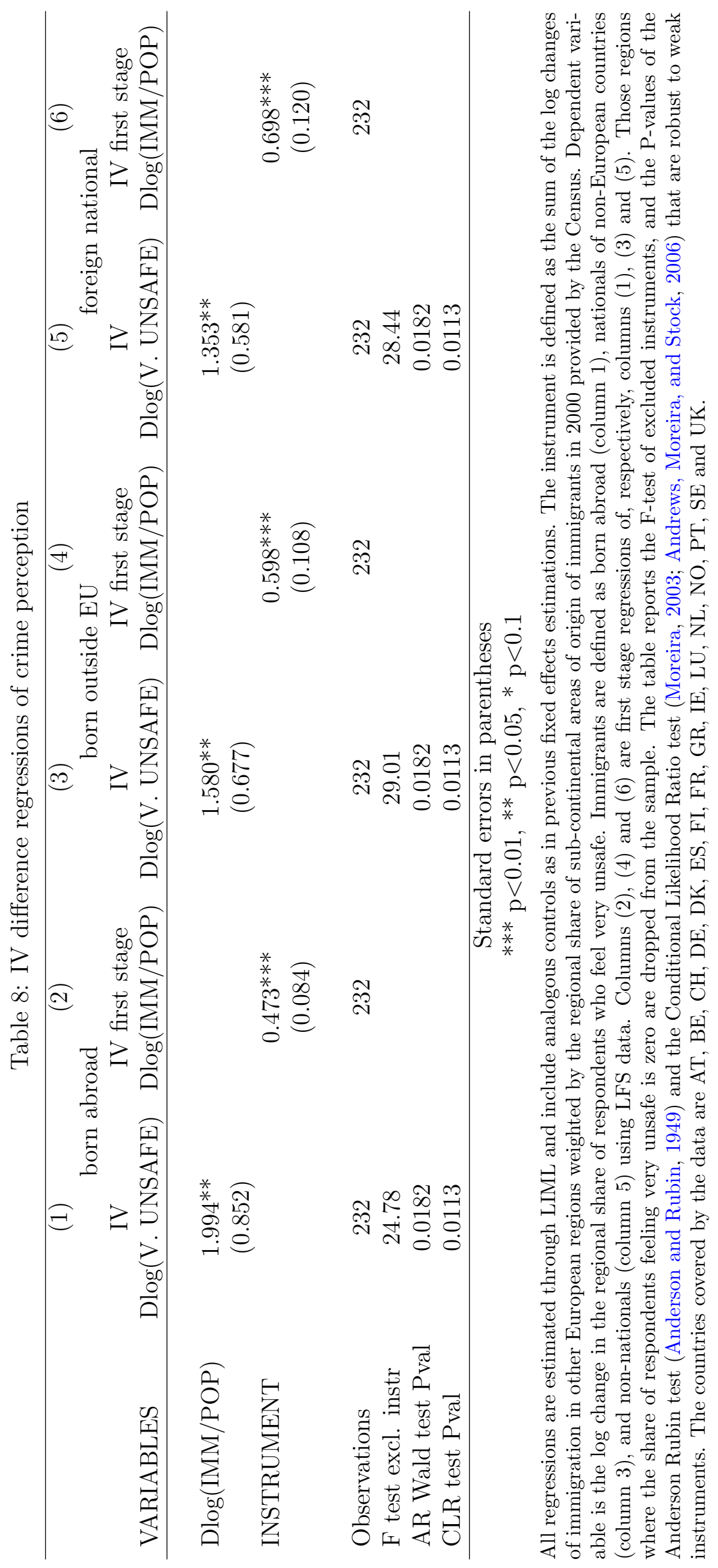


Table 9: Crime Perception and Attitudes Towards Immigration

\begin{tabular}{lllll}
\hline VARIABLES & $\begin{array}{l}(1) \\
\text { Immigrants } \\
\text { make } \\
\text { country worse }\end{array}$ & $\begin{array}{l}(2) \\
\text { Allow } \\
\text { immigrants from } \\
\text { outside Europe }\end{array}$ & $\begin{array}{l}\text { Immigrants } \\
\text { make } \\
\text { country worse }\end{array}$ & $\begin{array}{l}\text { Allow } \\
\text { immigrants from } \\
\text { outside Europe }\end{array}$ \\
\hline CRIMEVICTIM & $0.012^{* * *}$ & $0.010^{* *}$ & $0.011^{* *}$ & $0.011^{* *}$ \\
& $(0.004)$ & $(0.004)$ & $(0.004)$ & $(0.004)$ \\
UNSAFE & $0.124^{* * *}$ & $-0.075^{* * *}$ & $0.104^{* * *}$ & $-0.066^{* * *}$ \\
VERY UNSAFE & $(0.005)$ & $(0.004)$ & $(0.005)$ & $(0.004)$ \\
& & & $0.098^{* * *}$ & $-0.043^{* * *}$ \\
& & & $(0.008)$ & $(0.009)$ \\
Observations & 102,331 & 102,463 & 102,331 & 102,463 \\
R-squared & 0.123 & 0.149 & 0.124 & 0.149 \\
Regional FE & YES & YES & YES & YES \\
Country X Year FE & YES & YES & YES & YES \\
Clustered SE & YES & YES & YES & YES \\
\hline
\end{tabular}

Robust standard errors in parentheses

$* * * \mathrm{p}<0.01,{ }^{* *} \mathrm{p}<0.05,{ }^{*} \mathrm{p}<0.1$

Columns (1) and (2) are linear probability models of attitude towards immigration on individual data, controlling for regional fixed effects, country-specific time dummies and the usual set of controls, with standard errors clustered by region. Columns (3) and (4) are regional fixed effects regressions on collapsed data at the regional level, with standard errors clustered by country. The dependent variable in columns (1) and (3) is whether immigrants make country worse (i.e. respondents who answer less than or equal 4 , on a scale from 0 to 10 , from worse to better). The dependent variable in columns (2) and (4) indicates whether many or some immigrants from poorer countries outside Europe should be allowed to come and live in the country (as opposed to few and none). The countries covered by the data are AT, BE, CH, DE, DK, ES, FI, FR, GR, IE, LU, NL, NO, PT, SE and UK. 


\section{A Appendix}

\section{A.1 Variable Definitions, Sources and Summary Statistics}

Crime victimization: whether the respondent or household member has been a victim of assault or burglary in the last 5 years. Source: ESS.

Crime perception: dummy variable constructed using the feeling of safety when walking alone in local area after dark. Two definitions are used, with different degrees of stringency: very unsafe only, or unsafe and very unsafe. Source: ESS.

Immigration penetration: $\log$ (migrant/resident population), where migrant is defined as non-national, or born-abroad, or born in Europe or born outside Europe. Source: authors' calculation using LFS data.

Financial Wealth: whether main source of income of respondent's household is financial. Source: ESS.

Educational attainment, years of education, degree of urbanization of local area, age, gender, labour market status and political orientation. Source: ESS.

Share of immigrants by world flow area of origin in 2000 by region. Source: Eurostat Census.

Summary statistics are displayed in Table A.1. The correlations between alternative measures of immigration penetration by region are reported in Table A.2.

\section{TABLES A.1 AND A.2 AROUND HERE}

\section{A.2 European Regions in the Sample}

Our baseline sample consists of individuals residing in the period 2002-2008 in 16 western European countries, i.e. Austria, Belgium, Switzerland, Germany, Denmark, Spain, Finland, France, Greece, Ireland, Luxembourg, Netherlands, Norway, Portugal, Sweden and the UK, and 127 regions whose NUTS codes are the following:

AT11, AT12, AT13, AT21, AT22, AT31, AT32, AT33, AT34, BE1, BE2, BE3, CH01, CH02, CH03, CH04, CH05, CH06, CH07, DE1, DE2, DE3, DE4, DE5, DE6, DE7, DE8, DE9, DEA, DEB, DEC, DED, DEE, DEF, DEG, DK0, ES11, ES12, ES13, ES21, ES22, ES23, ES24, ES30, ES41, ES42, ES43, ES51, ES52, ES53, ES61, ES62, ES63, ES70, FI13, FI18, 
FI19, FI1A, FR1, FR2e, FR2w, FR3, FR4, FR5, FR6, FR7, FR8, GR11, GR12, GR13, GR14, GR21, GR22, GR23, GR24, GR25, GR30, GR41, GR42, GR43, IE01, IE02, LU0, NL11, NL12, NL13, NL21, NL22, NL23, NL31, NL32, NL33, NL34, NL41, NL42, NO01, NO02, NO03, NO04, NO05, NO06, NO07, PT11, PT15, PT16, PT17, PT18, SE11, SE12, SE21, SE22, SE23, SE31, SE32, SE33, UKC, UKD, UKE, UKF, UKG, UKH, UKI, UKJ, UKK, UKL, UKM, UKN.

Regional codes are NUTS 2 with the exception of Belgium, France, Germany, Denmark, Luxembourg and the UK whose regional codes are NUTS 1.

Note that for a small number of region \year combinations the ESS immigration share of non-nationals and those born outside Europe is missing whereas the LFS measure is not. This explains the discrepancy between the number of observations of the fixed effects regressions using LFS data in Table 3 and the SSIV regressions using both ESS and LFS data in Table 6.

When considering non-national immigrants, the ESS immigration penetration is missing for AT11 (2004), DE4 (2004), DE8 (2004 and 2008), DEB (2008), DEE (2002 and 2004), DEG (2008), ES1(2002), FI1A (2004 and 2008), NL11 (2002, 2006, 2008), NL12 (2002, 2006, 2008), NL13 (2002, 2006), NL21 (2006), PT18 (2006), SE32 (84), UKC (2002, 2008). When considering immigrants born outside Europe, the ESS immigration penetration is missing for AT11(2004), PT18(2002) and UKN (2002, 2008).

\section{A.3 Monte Carlo Simulations of Attenuation Bias from Sampling Error in Immigration Shares}

We investigate the extent of attenuation bias in our setting by means of Monte Carlo simulations using an artificial population of 10 millions individuals distributed across 100 regions. We assume a given share of immigration per region equal to 10 percent (in the order of the average immigration share in our sample) that each period, and for four subsequent periods, like in our data, is subject to a random positive immigration shock that varies across regions plus a random positive shock common to all regions. The shock is generated from a uniform distribution designed so that the total immigration share increases from 10 percent to 13.7 percent in four periods (i.e. we mimic the dynamics in the four biannual ESS waves that cover the 8 years period from 2002 to 2008). 
We then construct a population model of crime victimization where the probability of being a crime victim is given by:

$$
\text { crime }_{\text {rit }}=\beta m_{r t}+\mu_{r}+\mu_{t}+\varepsilon_{i t},
$$

where $m_{r t}$ is the resulting immigration share in each region and year, $\mu_{r}$ is a set of regional fixed effects on victimization, assuming the 100 regions are characterized by different degrees of criminality and ranked from the safest to the most dangerous, $\mu_{t}$ is a set of year random effects generated from a uniform distribution and $\varepsilon_{i t}$ is a normally distributed random disturbance with $\varepsilon_{i t} \sim N(0,0.05)$. We assume $\beta=1$ so that the resulting average probability to be a crime victim is equal to 20 percent like in our data.

We then draw 500 random samples, using different sampling rates (from 1/10000 to 30/100) and we estimate our fixed effects model (i.e. including region and year fixed effects) in each of the 500 random samples, producing an averaged estimated coefficient of interest $\hat{\beta}$ and standard error across the 500 replications. Our aim is to check the extent of the attenuation bias for randomly drawn samples of different sizes, i.e. for region/year cells of different sizes.

Table A.3 reports the findings of our Monte Carlo simulations where the average sample cell size used to calculate the immigration share varies with the sampling rate. Despite the average immigration share is very precisely estimated even for very low sampling rates, the attenuation bias can be large in fixed effects estimations when the sampling rate is low. Our simulations show that in presence of a unitary effect of immigration on crime at the population level we observe a 52 percent bias when the sampling rate equals 5/1000 (average cell size of 522), 35 percent bias when the sampling rate equals 1/100 (average cell size of 1043) and 15 percent bias when the sampling rate equals 3/100 (average cell size of 3130). However a positive, albeit biased, and statistically significant effect of immigration on crime is found even when the sampling rate is as low as 5/10000 (average cell size of 52).

Table A.4 displays the average LFS cell sizes used to calculate the regional immigration share in each country and year. The latter varies between 2977 and 115508 according to country, with a total average of 13451. This indicates that our fixed effects estimates should identify a significant effect of immigration on crime victimization if present, and that the attenuation bias should not be too large in our data.

Table A.5 presents the results of similar simulations performed adopting a SSIV specification where we use two alternative measures of the immigration share by region/year. The first (the 
instrumented immigration share, $m_{1}$ ) is obtained from a small sample analogous to the ESS sample, with sampling rates varying from 1/1000 (average cell size of 104) to 1/100 (average cell size of 1043). The second (the instrumenting immigration share, $m_{2}$ ) is obtained from a large sample analogous to the LFS sample, with sampling rates varying from 1/1000 to 10/100 (average cell size of 10433) and reported by column.

Our SSIV model largely outperforms the fixed effects model, with a resulting very small attenuation bias even for very low sampling rates. When the $m_{1}$ sampling rate equals $1 / 1000$ (average cell size of 104), the bias is consistently lower than 5 percent for $m_{2}$ sampling rates equal to or greater than 5/1000 (average cell size of 522). The bias is consistently lower that 1 percent when the $m_{1}$ sampling rate is equal to or greater than $5 / 1000$. In addition, the first stage coefficients are always positive and highly significant, especially when the $m_{2}$ sampling rate is equal to or greater than 3/1000 (average cell size of 313).

\section{A.4 Additional Tables}


Table A.1: Summary statistics, by country

\begin{tabular}{|c|c|c|c|c|c|}
\hline Country & $\begin{array}{l}\text { Foreign } \\
\text { Nationals }\end{array}$ & $\begin{array}{l}\text { Born } \\
\text { Abroad }\end{array}$ & $\begin{array}{l}\text { Crime } \\
\text { Victims }\end{array}$ & $\begin{array}{l}\text { Feeling } \\
\text { Unsafe }\end{array}$ & $\begin{array}{l}\text { Feeling } \\
\text { V.Unsafe }\end{array}$ \\
\hline$\overline{\mathrm{AT}}$ & 9.6 & 15.2 & 9.8 & 16.5 & 2.6 \\
\hline $\mathrm{BE}$ & 7.3 & 10.4 & 25.5 & 20.2 & 4.0 \\
\hline $\mathrm{CH}$ & 30.9 & 33.5 & 17.2 & 16.6 & 2.3 \\
\hline $\mathrm{DE}$ & 5.4 & 5.4 & 10.2 & 24.0 & 4.9 \\
\hline DK & 3.4 & 5.6 & 24.6 & 13.1 & 3.5 \\
\hline $\mathrm{ES}$ & 4.0 & 5.6 & 21.8 & 23.8 & 4.7 \\
\hline FI & 1.4 & 2.3 & 30.6 & 11.2 & 1.5 \\
\hline FR & 4.9 & 10.2 & 26.2 & 25.9 & 9.4 \\
\hline GB & 4.8 & 8.3 & 25.0 & 35.8 & 10.8 \\
\hline GR & 4.2 & 5.5 & 18.0 & 30.2 & 8.8 \\
\hline IE & 4.8 & 8.3 & 18.8 & 29.8 & 8.0 \\
\hline $\mathrm{LU}$ & 32.7 & 27.4 & 24.3 & 23.8 & 6.2 \\
\hline NL & 3.9 & 12.0 & 18.9 & 19.6 & 3.1 \\
\hline $\mathrm{NO}$ & 3.7 & 7.1 & 22.8 & 10.3 & 1.9 \\
\hline $\mathrm{PT}$ & 2.4 & 5.4 & 16.5 & 26.1 & 4.6 \\
\hline $\mathrm{SE}$ & 4.5 & 12.0 & 25.9 & 16.7 & 3.8 \\
\hline Total & 7.2 & 10.4 & 20.6 & 21.4 & 4.9 \\
\hline Country & Age & Male & & $\begin{array}{l}\text { Financial } \\
\text { Wealth }\end{array}$ & $\begin{array}{l}\text { Years of } \\
\text { Education }\end{array}$ \\
\hline $\mathrm{AT}$ & 43.8 & 46.3 & & 0.3 & 12.3 \\
\hline $\mathrm{BE}$ & 44.4 & 48.9 & & 0.4 & 12.3 \\
\hline $\mathrm{CH}$ & 47.4 & 45.7 & & 0.8 & 11.5 \\
\hline $\mathrm{DE}$ & 46.5 & 49.5 & & 0.4 & 13.1 \\
\hline DK & 46.9 & 49.5 & & 0.6 & 13.1 \\
\hline ES & 45.2 & 48.3 & & 0.1 & 11.0 \\
\hline FI & 46.2 & 48.1 & & 0.4 & 12.4 \\
\hline FR & 46.6 & 46.0 & & 0.3 & 12.2 \\
\hline GB & 47.6 & 45.7 & & 0.8 & 13.0 \\
\hline GR & 49.9 & 43.5 & & 0.7 & 9.8 \\
\hline IE & 46.0 & 44.4 & & 0.4 & 12.7 \\
\hline LU & 43.8 & 49.6 & & 0.3 & 11.9 \\
\hline NL & 47.9 & 44.4 & & 0.5 & 12.9 \\
\hline $\mathrm{NO}$ & 44.9 & 52.4 & & 0.6 & 13.3 \\
\hline $\mathrm{PT}$ & 48.7 & 39.7 & & 0.2 & 7.4 \\
\hline $\mathrm{SE}$ & 45.9 & 50.2 & & 0.3 & 12.3 \\
\hline Total & 46.4 & 47.0 & & 0.4 & 12.0 \\
\hline
\end{tabular}

Sample averages of main variables. Immigration measures are calculated from LFS data. 
Table A.2: Correlations between alternative measures of \% immigrants across European regions in 2002

\begin{tabular}{lccc}
\hline \hline \multicolumn{1}{c}{ Variables } & Census 01 & LFS, non-nat. & LFS, b.abr. \\
\hline Census 01 & 1.000 & & \\
LFS, non-nat. & 0.899 & 1.000 & \\
LFS, b.abr. & 0.921 & 0.882 & 1.000 \\
\hline \hline
\end{tabular}




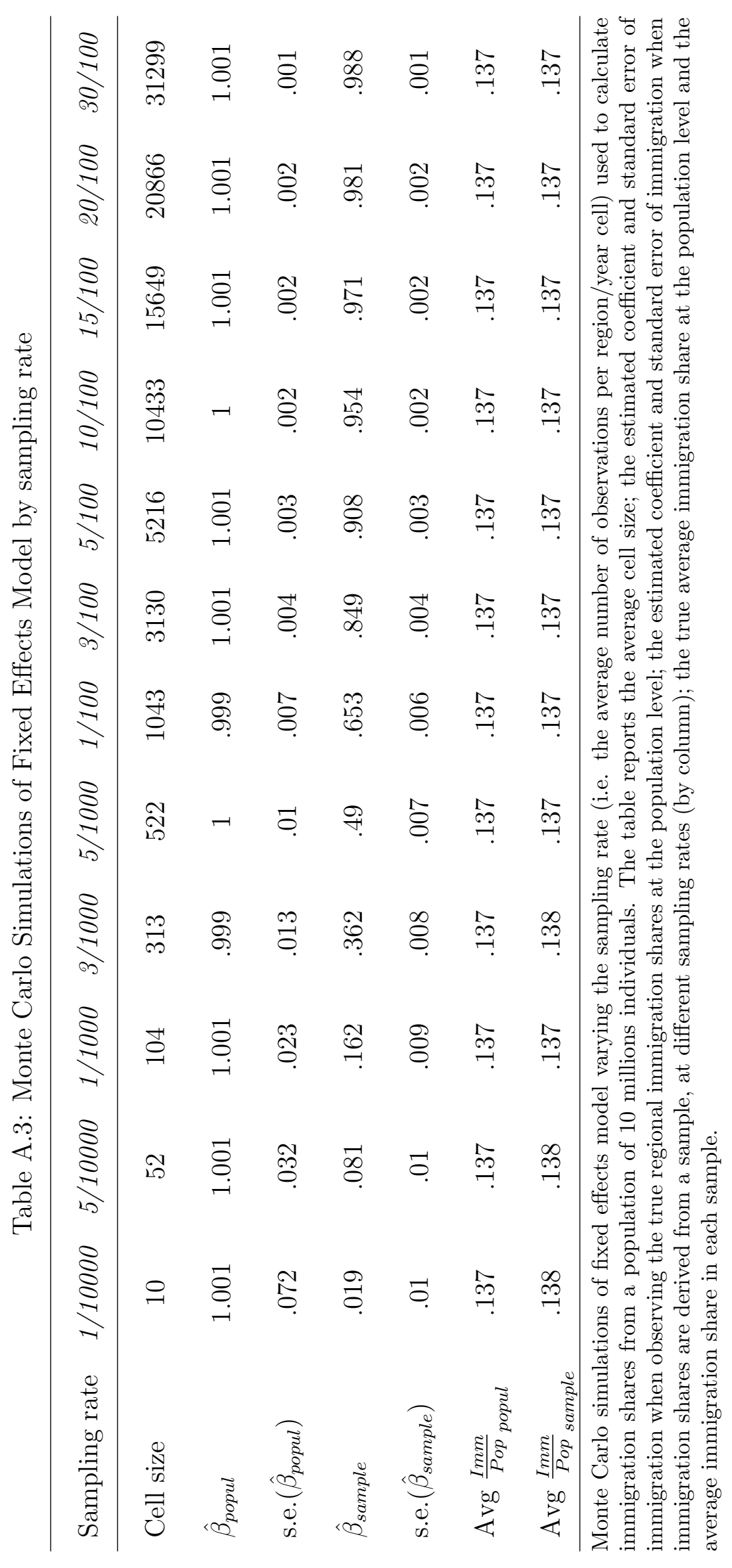


Table A.4: Region/year cell size by country in LFS data

\begin{tabular}{lccccc}
\hline country & 2002 & 2004 & 2006 & 2008 & Total \\
& & & & & \\
\hline AT & 6524 & 5021 & 22343 & 21563 & 12632 \\
BE & 6958 & 6935 & 28570 & 26401 & 17976 \\
CH & 5895 & 7747 & 6895 & 6843 & 7230 \\
DE & 20505 & 20443 & 3105 & 2995 & 10971 \\
DK & 16081 & 15445 & 58899 & 115508 & 49326 \\
ES & 9082 & 9219 & 5594 & 5763 & 10170 \\
FI & 8549 & 7936 & 7671 & 12191 & 9459 \\
FR & 19549 & 9753 & 37753 & 38729 & 29068 \\
GB & 11346 & 10468 & 10054 & 16136 & 10893 \\
GR & 5958 & 6230 & 23355 & 22586 & 14503 \\
IE & 52784 & 43272 & 42867 & 37184 & 64662 \\
LU & 13429 & 21189 & 85080 & 14288 & 25759 \\
NL & 8133 & 9409 & 9045 & 9132 & 8279 \\
NO & 2977 & 3044 & 2952 & 2880 & 3601 \\
PT & 6517 & 7245 & 25648 & 23996 & 16229 \\
SE & 6876 & 6436 & 25889 & 25505 & 16544 \\
Total & 11185 & 10343 & 15948 & 16329 & 13451 \\
\hline
\end{tabular}

Average region/year cell size by country in LFS data. 
Table A.5: Monte Carlo Simulations of SSIV Model by sampling rate

\begin{tabular}{|c|c|c|c|c|c|c|c|}
\hline Sampling rate & $1 / 1000$ & $3 / 1000$ & $5 / 1000$ & $1 / 100$ & $3 / 100$ & $5 / 100$ & $10 / 100$ \\
\hline Cell size & 104 & 313 & 522 & 1043 & 3130 & 5216 & 10433 \\
\hline$\hat{\beta}_{\text {popul }}^{F E}$ & 1 & .998 & 1.001 & .999 & .999 & 1 & 1 \\
\hline s.e. $\left(\hat{\beta}_{\text {popul }}^{F E}\right)$ & .02 & .011 & .009 & .006 & .004 & .003 & .002 \\
\hline$\hat{\beta}_{\text {sample }}^{F E}$ & .153 & .356 & .483 & .65 & .851 & .909 & .953 \\
\hline s.e. $\left(\hat{\beta}_{\text {sample }}^{F E}\right)$ & .008 & .007 & .006 & .005 & .003 & .003 & .002 \\
\hline$\hat{\beta}_{\text {sample } 1 / 1000}^{I V}$ & 1.053 & 1.089 & 1.012 & 1.041 & 1.025 & 1.006 & 1.026 \\
\hline s.e. $\left(\hat{\beta}_{\text {sample } 1 / 1000}^{I V}\right)$ & .081 & .025 & .015 & .01 & .005 & .003 & .002 \\
\hline$\hat{\beta}_{\text {sample } 1 / 1000}^{I V F S}$ & .148 & .345 & .501 & .645 & .849 & .92 & .953 \\
\hline s.e. $\left(\hat{\beta}_{\text {sample } 1 / 1000}^{I V F S}\right)$ & .005 & .004 & .004 & .003 & .002 & .002 & .001 \\
\hline$\hat{\beta}_{\text {sample } 3 / 1000}^{I V}$ & 1.001 & 1.03 & 1.024 & .994 & 1.002 & .992 & 1.013 \\
\hline s.e. $\left(\hat{\beta}_{\text {sample } 3 / 1000}^{I V}\right)$ & .055 & .021 & .014 & .008 & .004 & .003 & .002 \\
\hline$\hat{\beta}_{\text {sample } 3 / 1000}^{I V F S}$ & .158 & .352 & .478 & .661 & .855 & .921 & .948 \\
\hline s.e. $\left(\hat{\beta}_{\text {sample } 3 / 1000}^{I V F S}\right)$ & .003 & .003 & .002 & .002 & .001 & .001 & .001 \\
\hline$\hat{\beta}_{\text {sample } 5 / 1000}^{I V}$ & 1.003 & .995 & 1.008 & 1.001 & 1.01 & 1.009 & 1.001 \\
\hline s.e. $\left(\hat{\beta}_{\text {sample } 5 / 1000}^{I V}\right)$ & .054 & .02 & .013 & .008 & .004 & .003 & .002 \\
\hline$\hat{\beta}_{\text {sample } 5 / 1000}^{I V F S}$ & .156 & .363 & .481 & .653 & .846 & .905 & .956 \\
\hline s.e. $\left(\hat{\beta}_{\text {sample } 5 / 1000}^{I V F S}\right)$ & .003 & .002 & .002 & .001 & .001 & .001 & .001 \\
\hline$\hat{\beta}_{\text {sample } 1 / 100}^{I V}$ & .998 & 1.007 & 1.023 & 1 & 1.004 & 1 & .996 \\
\hline s.e. $\left(\hat{\beta}_{\text {sample } 1 / 100}^{I V}\right)$ & .053 & .02 & .013 & .008 & .004 & .003 & .002 \\
\hline$\hat{\beta}_{\text {sample } 1 / 100}^{I V F S}$ & .155 & .354 & .474 & .652 & .849 & .911 & .959 \\
\hline s.e. $\left(\hat{\beta}_{\text {sample } 1 / 100}^{I V F S}\right)$ & .002 & .002 & .002 & .001 & .001 & .001 & 0 \\
\hline
\end{tabular}

Monte Carlo simulations of Fixed Effects and SSIV model varying the sampling rate (i.e. the average number of observations per region/year cell) used to calculate immigration shares from a population of 10 millions individuals. All reported statistics are averages across 500 replications of random samples at the given sampling rate. The table reports the average cell size; the estimated fixed effects coefficient and standard error of immigration when observing the true regional immigration shares at the population level; the estimated fixed effects coefficient and standard error of immigration when immigration shares are calculated from sample, at different sampling rates (by column); the estimated SSIV coefficient and standard error of immigration for different sampling rates of the sample used to derive the instrumented immigration share (by row); the first stage estimated SSIV coefficient and standard error for different sampling rates of second sample; the true average immigration share at the population level and the average immigration share in each sample. 